\title{
Mimicking the Catalytic Center for the Water-Splitting Reaction in Photosystem II
}

\author{
Yanxi Li ${ }^{1,2,+} \mathbb{1}$, Ruoqing Yao ${ }^{1,2,+}$, Yang Chen ${ }^{1,2}$, Boran $\mathrm{Xu}{ }^{1,2}$, Changhui Chen $1, * \mathbb{C}$ and \\ Chunxi Zhang ${ }^{1, *(D)}$ \\ 1 Laboratory of Photochemistry, Institute of Chemistry, Chinese Academy of Sciences, Beijing 100190, China; \\ liyanxi@iccas.ac.cn (Y.L.); yaoruoqing@iccas.ac.cn (R.Y.); chenyang18@iccas.ac.cn (Y.C.); \\ boranxu@iccas.ac.cn (B.X.) \\ 2 University of Chinese Academy of Sciences, Beijing 100049, China \\ * Correspondence: chenchanghui@iccas.ac.cn (C.C); chunxizhang@iccas.ac.cn (C.Z.) \\ + These authors contributed equally to this work.
}

Received: 30 December 2019; Accepted: 31 January 2020; Published: 3 February 2020

\begin{abstract}
The oxygen-evolving center (OEC) in photosystem II (PSII) of plants, algae and cyanobacteria is a unique natural catalyst that splits water into electrons, protons and dioxygen. The crystallographic studies of PSII have revealed that the OEC is an asymmetric $\mathrm{Mn}_{4} \mathrm{CaO}_{5}$-cluster. The understanding of the structure-function relationship of this natural $\mathrm{Mn}_{4} \mathrm{CaO}_{5}$-cluster is impeded mainly due to the complexity of the protein environment and lack of a rational chemical model as a reference. Although it has been a great challenge for chemists to synthesize the OEC in the laboratory, significant advances have been achieved recently. Different artificial complexes have been reported, especially a series of artificial $\mathrm{Mn}_{4} \mathrm{CaO}_{4}$-clusters that closely mimic both the geometric and electronic structures of the OEC in PSII, which provides a structurally well-defined chemical model to investigate the structure-function relationship of the natural $\mathrm{Mn}_{4} \mathrm{CaO}_{5}$-cluster. The deep investigations on this artificial $\mathrm{Mn}_{4} \mathrm{CaO}_{4}$-cluster could provide new insights into the mechanism of the water-splitting reaction in natural photosynthesis and may help the development of efficient catalysts for the water-splitting reaction in artificial photosynthesis.
\end{abstract}

Keywords: photosystem II; water-splitting reaction; natural $\mathrm{Mn}_{4} \mathrm{CaO}_{5}$-cluster; artificial $\mathrm{Mn}_{4} \mathrm{CaO}_{4}$-cluster

\section{Introduction}

The oxygen-evolving center (OEC) in photosystem II (PSII) of plants, algae and cyanobacteria is a unique natural catalyst that provides electrons and protons to produce the biomass or biofuel, and a dioxygen molecule to maintain the oxygenic atmosphere on our planet [1-8]. Due to its significantly fundamental interests and potential applications, the investigation of the OEC has attracted extensive attention during the last several decades. A long-standing goal in science seeks to reveal the structure-function relationship and the catalytic mechanism of the OEC, which would provide a blueprint to develop efficient artificial catalysts for the water-splitting reaction in artificial photosynthesis $[2,7,9,10]$.

It is well known that the water-splitting reaction involves five different redox states $\left(S_{n}, n=0-4\right)$ of the OEC (Figure 1) [11,12], wherein the $S_{0}$ state is the initial and most reduced state and the $S_{1}$ state is the dark-stable state. The $S_{2}$ and $S_{3}$ states are metastable and decay eventually to the dark-stable $S_{1}$ state, whereas the $S_{4}$ state is a transient state that releases dioxygen and decays to the $S_{0}$ state. In 1980s, it was revealed that the OEC is composed by one calcium and four manganese ions, embedded into the large protein environment of PSII through some carboxylate and imidazole groups [13-15]. Based 
on the X-ray absorption spectroscopy (XAS) and electron paramagnetic resonance (EPR) investigations of the OEC in different $\mathrm{S}$-states, it has been found that changes of the valences of the four manganese ions take place during the catalytic turnover [6,16-19]. The valences for the four manganese ions have been suggested to be $\mathrm{S}_{0}$ (III, III, III, IV) or (II, III, IV, IV), $\mathrm{S}_{1}$ (III, III, IV, IV), $\mathrm{S}_{2}$ (III, IV, IV, IV) and $\mathrm{S}_{3}$ (IV, IV, IV, IV) $[17,18,20,21]$. This is the "high-oxidation paradigm" that has been widely adopted in the field of photosynthetic research $[17,18,20,21]$. However, some groups proposed a low-oxidation paradigm, corresponding to $\mathrm{S}_{0}$ (II, III, III, III), $\mathrm{S}_{1}$ (III, III, III, III), or (II, III, III, IV), $\mathrm{S}_{2}$ (III, III, III, IV), and $\mathrm{S}_{3}$ (III, III, IV, IV), respectively [22-27]. The calcium is an indispensable cofactor for the function of the OEC, and its depletion results in the complete loss of the water oxidation capability of PSII and it can only be functionally replaced by strontium [28-30]. The structure and catalytic mechanism of the OEC have attracted extensive studies during the last three decades $[2,6,7]$.

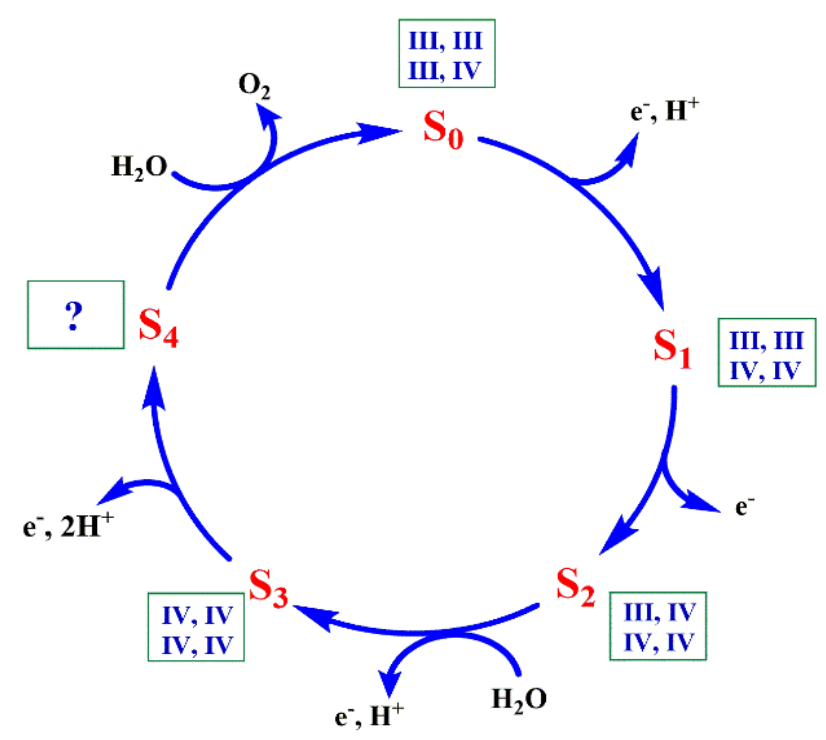

Figure 1. The turnover of the OEC in PSII. The valences of the four manganese ions in different $S$ states are according to the high-oxidation paradigm (see main text for details).

\section{Structure of the OEC}

It is a long-standing issue to reveal the detailed structure of the OEC in the field of photosynthetic research. Before the appearance of the crystal structure of PSII, most structural information of the OEC came from X-ray absorption spectroscopy (XAS) $[18,20]$, electron paramagnetic resonance (EPR) $[6,16,31]$ investigations, and theoretical calculations [32]. Different structural models were suggested to explain different experimental observations of the OEC in PSII [33-37]. Figure 2A shows the structural model proposed by Zhang et al. in $1999[37,38]$ in which, apart from all other models [33-36], the key component of calcium was suggested to be located in the middle of the OEC and connected with four manganese ions through three oxide bridges and two carboxylate groups [37]. 


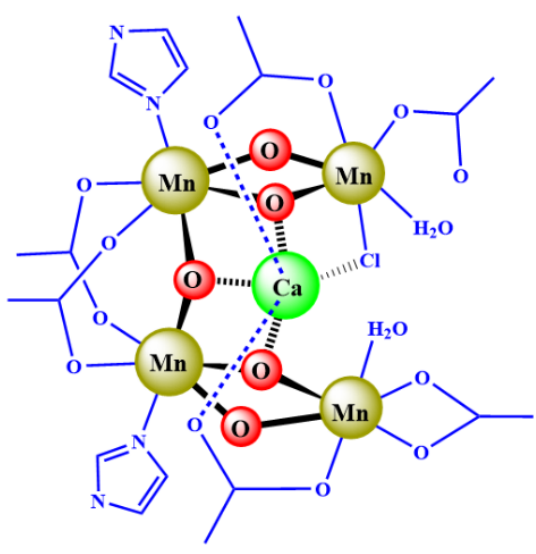

(A)

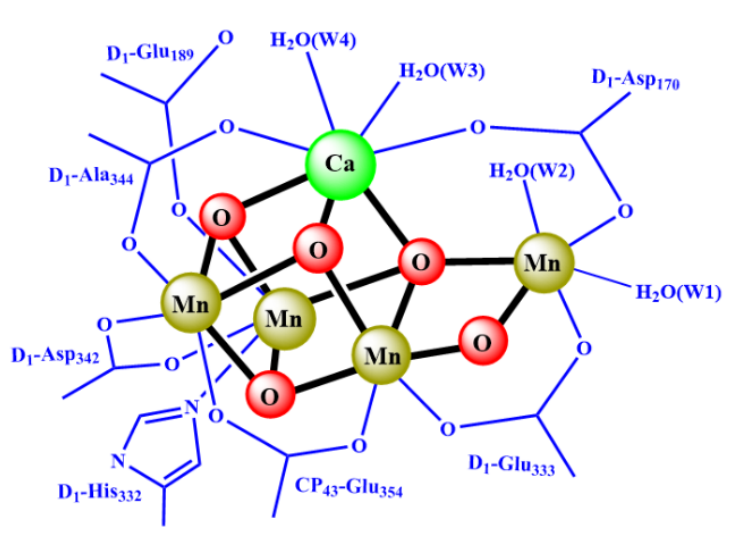

(B)

Figure 2. Scheme for the structural model [37,38] (A) and structure of the OEC [39] (B).

The crystal structure of the OEC has emerged since the beginning of this century [39-46]. In 2001, Zouni et al. [40] reported the first crystal structure of PSII from thermophilic cyanobacterium at a resolution of $3.8 \AA$. In 2004, Ferreira et al. [42] reported the structure of PSII at $3.5 \AA$ resolution, and proposed that the OEC could be comprised of a $\mathrm{Mn}_{3} \mathrm{CaO}_{4}$ cubane attached with a "dangler" $\mathrm{Mn}$ ion via one bridging oxide, which forms a $\mathrm{Mn}_{4} \mathrm{CaO}_{4}$-cluster. However, the detailed core and peripheral ligands of the OEC were still elusive due to the low resolution and the radiation reduction induced by the X-ray beam during the crystallographic structural determination [45,47-49].

The more detailed structure of the OEC was revealed by the crystal structure of PSII at a resolution of $1.9 \AA$ A reported by Umena et al. in 2011 [39]. In this structure, all possible binding ligands of the OEC have been clearly resolved, including four water molecules with one imidazole group from $\mathrm{D}_{1}-\mathrm{His}_{332}$ and six carboxylate groups from $\mathrm{D}_{1}-\mathrm{Asp}_{170}, \mathrm{D}_{1}-\mathrm{Glu}_{189}, \mathrm{D}_{1}-\mathrm{Glu}_{333}, \mathrm{D}_{1}-\mathrm{Asp}_{342}, \mathrm{D}_{1}-\mathrm{Ala}_{344}$, and $\mathrm{CP}_{43}-\mathrm{Glu}_{354}$, respectively. Importantly, one additional $\mu_{2}$-oxo $(\mathrm{O} 4)$ bridge linking the dangler $\mathrm{Mn}$ and $\mathrm{Mn}_{3} \mathrm{CaO}_{4}$ cubane in the OEC was observed (Figure 2B). The whole structure of the OEC is an asymmetric $\mathrm{Mn}_{4} \mathrm{CaO}_{5}$-cluster. In this structure, the key component, $\mathrm{Ca}^{2+}$, is located in the middle of the OEC and connected to the four manganese ions through three oxide bridges and two carboxylate groups, which is consistent with our previous proposal (Figure 2A) published in 1999 [37,38].

The structure of the OEC (Figure 2B) was further confirmed by the $1.95 \AA$ resolution data obtained by an X-ray free electron laser (XFEL) reported by Shen's group [50-52] and other groups [46,53]. It was also supported by the $2.44 \AA$ A resolution reported by Hellmich et al. [44] and the $1.87 \AA$ resolution reported by Tanaka et al. [54] when using a conventional synchrotron radiation source at an extremely low X-ray dose (0.03 MGy). Recently, the structure of the OEC in higher plants (e.g., spinach and pea) has also been revealed by single-particle cryo-electron microscopy (Cryo-EM) at the resolution of $3.2 \sim 2.7 \AA[55,56]$.

The structures of the $S_{2}$ and $S_{3}$ states of the OEC have also been reported recently by using XFEL, and it was found that a new oxygen (termed $\mathrm{O} 6$ or $\mathrm{O}_{\mathrm{X}}$ ) occupies the sixth coordination site of $\mathrm{Mn} 1$ during the $S_{2} \rightarrow S_{3}$ state transition [51-53]. The structures revealed by XFEL have been suggested to correspond to the native structure of the OEC in PSII [50]. However, consensus of the atomic positions of the $S_{1}$ state OEC revealed by XFEL is still not fully reached for all structures with the results of extended X-ray absorption fine structure (EXAFS) spectroscopy studies on the active sample $[49,57]$. To evaluate the oxidation valences of the four manganese ions in the structure of the OEC revealed by XFEL, we have carried out bond-valence sum (BVS) calculations [58,59]. The BVS method is a popular method in coordination chemistry to estimate the valences of atoms [60,61]. It is derived from the bond-valence model [60], which is a simple yet robust model for validating chemical structures with localized bonds or used to predict some of their properties. This method has been used extensively to estimate the oxidation state of the active site in various metalloenzymes as well $[62,63]$. Table 1 lists the 
results of the BVS calculations on the XFEL structures of the OEC in the 'native' $\mathrm{S}_{1}, \mathrm{~S}_{2}$, and $\mathrm{S}_{3}$ states, respectively. Surprisingly, the oxidation valences of the four manganese ions of all these states are remarkably lower than that of widely adopted $\mathrm{S}_{1}$ (III, III, IV, IV) in the field of photosynthetic research (Figure 1) [16-19]. It is likely that the reduction of the high valences of manganese ions in the OEC could take place during the structural determination. Alternatively, some significant changes of the coordination spheres of the manganese ions in the OEC could take place during the $\mathrm{X}$-ray diffraction measurement [57]. If it was the case, one would expect that the XFEL structures of the OEC would be different from the native structure of these intermediate states during the catalytic cycle. Recently, it has been found that the structural modifications of the OEC would take place due to the radiation damage induced by XFEL such as the position of the $\mu_{4}$-oxide bridge (O5, Figure 2), which can be significantly disturbed by XFEL $[57,64,65]$.

Table 1. Bond-valence sum (BVS) calculations on the structures of the OEC revealed at different resolutions in different $S$ states. Roman numerals in parentheses indicate the assignment of the possible oxidation valences of four manganese ions in the OEC based on BVS calculations. All atomic coordinates were taken from the first monomer of PSII in the crystal structure data with the Protein Data Bank (PDB) codes: 4UB6 [50], 5B5E [54], 6DHF [53], 6JLK [52], 6DHO [53], and 6JLL [52], respectively.

\begin{tabular}{|c|c|c|c|c|c|c|}
\hline & $\begin{array}{c}\mathrm{S}_{1}(1.95 \AA) \\
\text { (4UB6) }\end{array}$ & $\begin{array}{c}\mathrm{S}_{1}(1.87 \AA) \\
(5 \mathrm{~B} 5 \mathrm{E})\end{array}$ & $\begin{array}{c}\mathrm{S}_{2}(2.08 \AA) \\
(6 \mathrm{DHF})\end{array}$ & $\begin{array}{c}\mathrm{S}_{2}(2.15 \AA) \\
\text { (6JLK) }\end{array}$ & $\begin{array}{c}\mathrm{S}_{3}(2.07 \AA) \\
(6 \mathrm{DHO})\end{array}$ & $\begin{array}{c}\mathrm{S}_{3}(2.15 \AA) \\
(6 \mathrm{JLL})\end{array}$ \\
\hline Mn1 & 3.075 (III) & 3.244 (III) & 3.232 (III) & 3.204 (III) & 3.901 (IV) & 4.300 (IV) \\
\hline Mn2 & 3.237 (III) & 3.057 (III) & 4.316 (IV) & 3.775 (IV) & 4.193 (IV) & 3.852 (IV) \\
\hline Mn3 & 2.980 (III) & 2.951 (III) & 3.784 (IV) & 3.347 (III) & 3.232 (III) & 3.243 (III) \\
\hline Mn4 & 2.318 (II) & 2.603 (III) & 3.139 (III) & 2.597 (III) & 2.932 (III) & 2.531 (III) \\
\hline
\end{tabular}

\section{Mechanism for the Water-Splitting Reaction in the OEC}

Based on recent crystallographic studies [39,42,46,50-53], spectroscopic investigations, and theoretical calculations $[17,18,66-75]$, different proposals for the O-O bond formation have been suggested $[6,49,66,75-81]$. Figures $3-6$ show four typical proposals from different groups.

The mechanism in Figure 3 was suggested by Barber's group [77] in which the two oxygens of two water molecules (W2 and W3, Figure 2B) were proposed to serve as the oxygen sources for the formation of the $\mathrm{O}-\mathrm{O}$ bond. The key feature of this mechanism is that the $\mathrm{O}-\mathrm{O}$ bond is formed by a nucleophilic attack of a calcium ligated hydroxyl group onto an electrophilic oxo of $\mathrm{Mn}^{\mathrm{V}} \equiv \mathrm{O}$ or $\mathrm{Mn}^{\mathrm{IV}}-\mathrm{O}^{\bullet}$, derived from the deprotonation of the second substrate water molecule. Similar proposals have been suggested by other groups $[80,82,83]$. However, this proposal was not supported by a recent theoretical calculation reported by Siegbahn [84].

The second proposal for the mechanism of the water-splitting reaction was suggested by Ishikita's group, as shown in Figure 4 [79]. In this mechanism, the $\mu_{2}$-oxide bridge $(\mathrm{O} 4)$ and one water molecule (W1) were suggested to provide the oxygen atoms to form the $\mathrm{O}-\mathrm{O}$ bond. The key feature of this proposal is that the $\mathrm{O}-\mathrm{O}$ bond is formed through the coupling of a bridged oxo and an $\mathrm{Mn}(\mathrm{IV})-\mathrm{O}^{\bullet}$ oxyl radical. However, the valences (III, IV, IV, IV) of the four manganese ions in the $\mathrm{S}_{3}$ state were not consistent with the widely accepted valences of (IV, IV, IV, IV) $[17,18,20]$. 


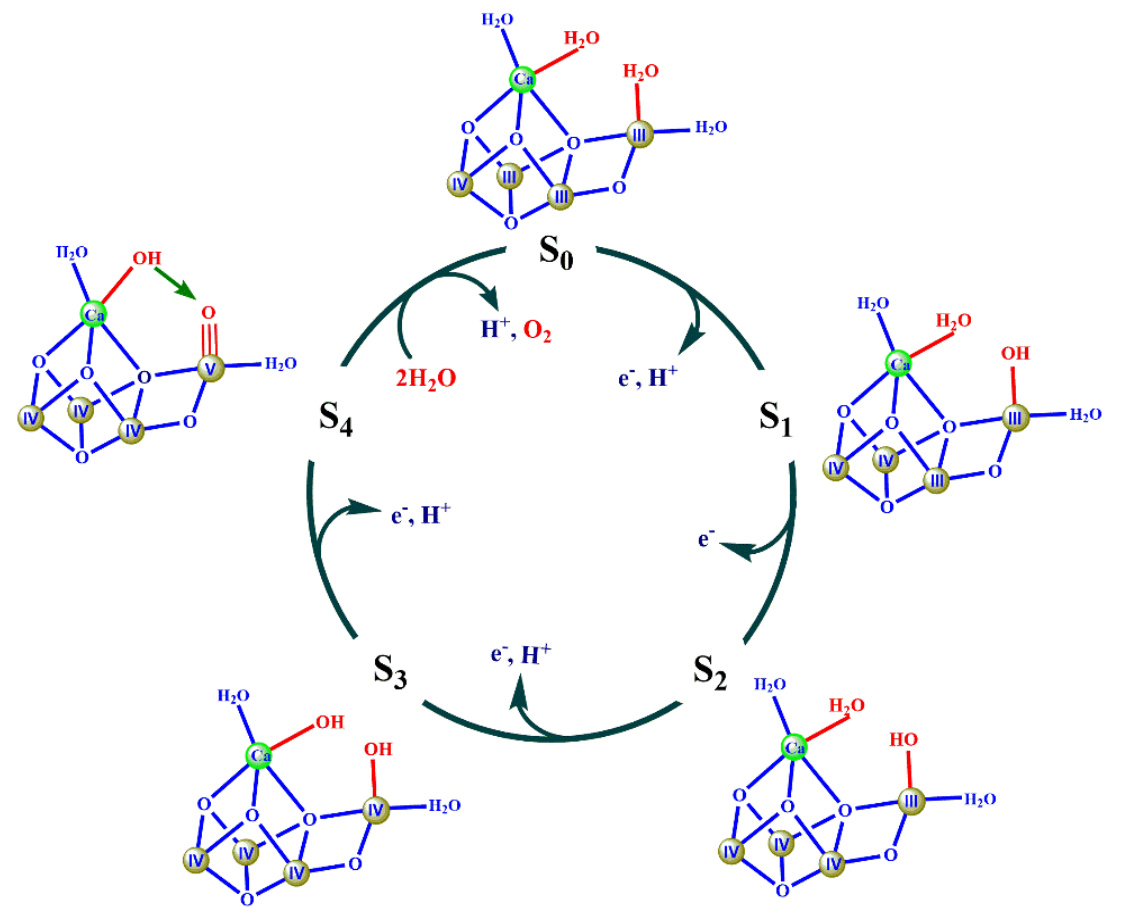

Figure 3. One possible mechanism for the water-splitting reaction by OEC suggested by Barber's group [77]. Significant changes during the catalytic cycle are given in a red color. Mn and Ca are shown in brown and green, respectively. Roman numerals indicate the oxidation states of manganese ions. For clarity, all protein ligands of the OEC are omitted.

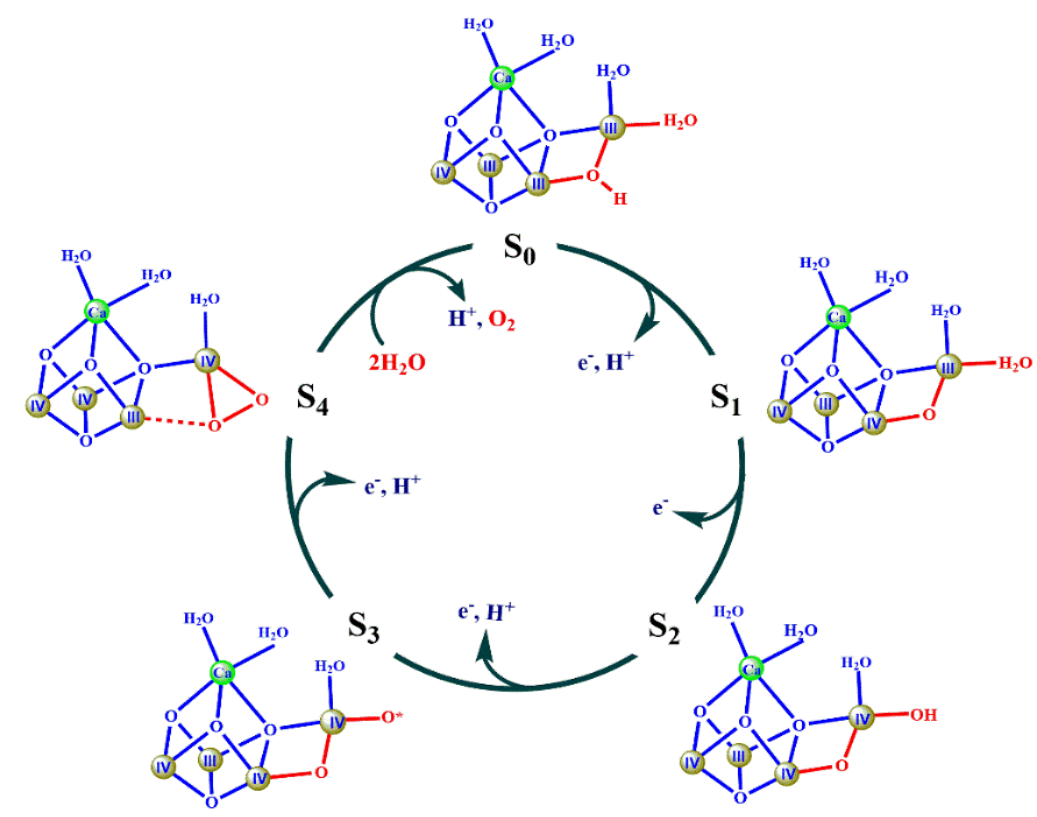

Figure 4. The second proposal for the $\mathrm{O}-\mathrm{O}$ bond formation involving the $\mu_{2}$-oxide bridge (O4) and one water molecule (W1) on the dangler Mn [79]. All other depictions are the same as that in Figure 3. For clarity, all protein ligands of the OEC are omitted. The proton released during the $S_{3} \rightarrow S_{4}$ state transition is from $\mathrm{D}_{1}-\mathrm{Asp}_{61}$ instead of the binding water molecule.

The third mechanism was first suggested by Siegbahn based on theoretical calculations [67] (Figure 5). The main feature of this proposal is that the $\mu_{4}$-oxide bridge (O5) serves as the active site for the $\mathrm{O}-\mathrm{O}$ bond formation. According to this mechanism, the release of $\mathrm{O}_{2}$ from the $\mathrm{S}_{4}$ state would result in the formation of four unsaturated metal ions, which includes three 5-coordinated manganese (i.e., 
$\mathrm{Mn} 1, \mathrm{Mn} 3, \mathrm{Mn} 4)$ and one 6-coordinated calcium. This could certainly require very high activation energy [85]. Thus, one would expect that the dioxygen release could be the rate-limited step during the catalytic cycle. However, this is inconsistent with the fast release of the $\mathrm{O}_{2}$ observed in the natural system $[2,86]$. Although some spectroscopic studies [6,74] show experimental evidence to support this proposal to some degree [78], it is still an open question whether the $\mathrm{Mn} 1$ is the active site for the binding site of the second substrate water molecule $[2,7,58,59]$. In addition, it is also noted that the suggestion of the protonated $\mu_{4}$-oxide bridge (i.e., $\mathrm{OH}$ ) for $\mathrm{O} 5$ in the $\mathrm{S}_{0}$ state has not been supported by the theoretical studies from the other group $[65,87]$.

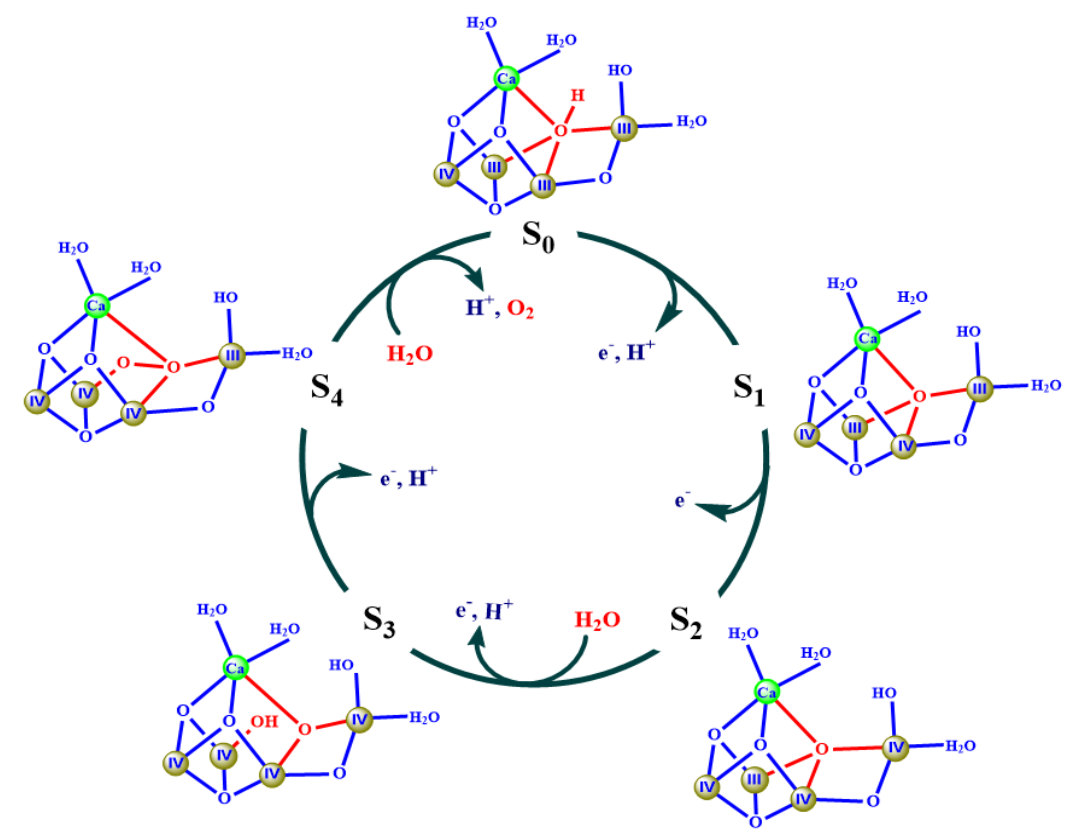

Figure 5. The third proposal for the O-O bond formation involving the $\mu_{4}$-oxide bridge (O5) $[52,67,78]$. All other depictions are the same as that in Figure 3. For clarity, all protein ligands of the OEC are omitted.

Figure 6 shows a hypothesis proposed by Zhang and Sun [88]. In all previous proposals, the highest oxidation valance of the manganese ion was $\mathrm{Mn}^{\mathrm{V}}$ (e.g., Figure 3). Remarkably, in the proposal shown in Figure 6, the authors suggested that the highest oxidation valance of the manganese ion, $\mathrm{Mn} V \mathrm{VII}$, could be present in the $\mathrm{S}_{4}$ state induced by charge and structural rearrangements of the first coordination spheres around the $\mathrm{Mn}^{\mathrm{VII}}$-oxo site on the dangling $\mathrm{Mn} 4$ with de-coordination and re-coordination of carboxylates $\left(\mathrm{D}_{1}-\mathrm{Glu}_{333}\right.$ and $\mathrm{D}_{1}$-Asp $\left.\mathrm{Ap}_{170}\right)$ [88]. Generally, $\mathrm{Mn}^{\mathrm{VII}}$ ion displays a special UV-visible absorption at a range of $400-600 \mathrm{~nm}$. Therefore, if this is the case, one could observe the typical $\mathrm{Mn}^{\mathrm{VII}}$ absorption feature during the turnover of the catalytic cycle.

As mentioned above, although various mechanisms for the water-splitting reaction have been proposed $[67,77,79,80,82,89,90]$, the detailed mechanism for the O-O bond formation is still elusive $[2,7,59]$ mainly due to the complexity of the huge protein environment and the dynamic structural changes of the OEC during the water-splitting reaction. In this regard, precisely structural data for different $S$ states of the OEC are still highly required in the future $[46,51-53,77,85]$. 


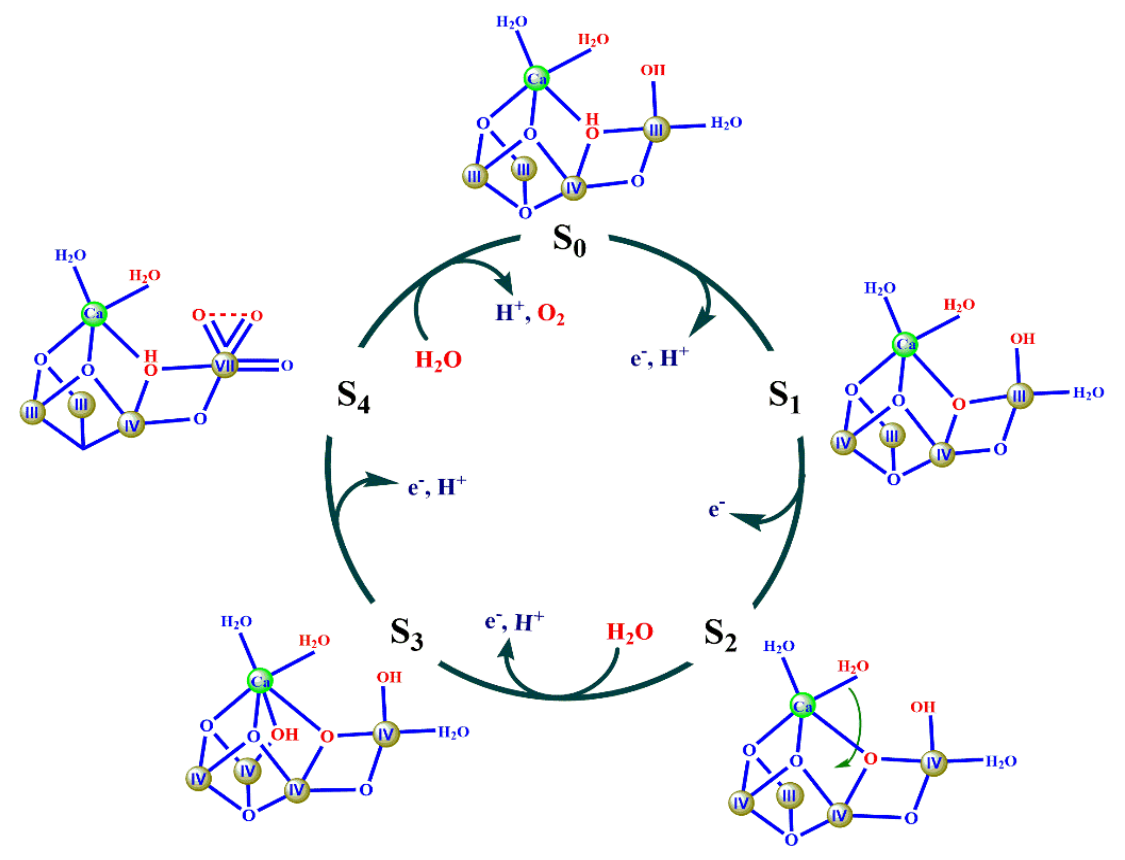

Figure 6. The hypothesis for the $\mathrm{O}-\mathrm{O}$ bond formation involving a $\mathrm{Mn}^{\mathrm{VII}}$ species [88]. All other depictions are the same as that in Figure 3. For clarity, all protein ligands of OEC are omitted. During the $S_{3} \rightarrow S_{4}$ state transition, two protons of two hydroxide groups bound to the dangling manganese ion are delivered to $\mathrm{D}_{1}-\mathrm{Asp}_{170}$ and $\mathrm{D}_{1}-\mathrm{Glu}_{333}$, respectively [88].

\section{Challenge for the Synthesis of the OEC in the Laboratory}

In order to better understand the structure and properties of the OEC as well as to develop highly efficient and cheap man-made catalysts for the water-splitting reaction to overcome the bottleneck of the artificial photosynthesis, many groups have tried to synthesize the OEC in the laboratory since the 1990s. However, it was a great challenge for chemists to synthesize the whole structure of the OEC due to several reasons $[38,91]$ including: i) It is very difficult to incorporate $\mathrm{Ca}^{2+}$ into the $\mathrm{Mn}_{4}$-cluster through $\mu$-oxo bridges because the affinity of $\mathrm{Ca}^{2+}$ to $\mu$-oxo is significantly weaker than that of the $\mathrm{Mn}$ ion. In general, only a homometallic cluster, instead of the heterometallic manganese-calcium cluster, can be isolated. ii) The core structure of the OEC is an asymmetric $\mathrm{Mn}_{4} \mathrm{Ca}$-cluster [1]. It was fully unknown whether such an asymmetric structure could be synthesized in a chemical system. iii) The ligands of the natural OEC are mainly composed of carboxylate groups and water molecules, which are drastically different from the multi-pyridine ligands used in most previous chemical model systems [92-95]. iv) The redox potential of the OEC is very high $(+0.8 \sim+1.0 \mathrm{~V}$ vs. normal hydrogen electrode(NHE) $[4,96]$ due to the presence of the high valence $\mathrm{Mn}(\mathrm{IV}) / \mathrm{Mn}(\mathrm{III})$ ions.

A large number of artificial Mn complexes have been reported in the literature [82,92,95,97-104]. Among them, tetra-manganese complexes containing $\mathrm{Mn}_{4} \mathrm{O}_{4}$-cubane [101,105-108] are attractive. However, both the structure and properties of most model complexes are remarkably different from that of the OEC in a natural system.

Significant advances for the synthesis of the OEC have emerged since 2011. Agapie's group reported the first artificial $\mathrm{Mn}_{3} \mathrm{CaO}_{4}$-cluster using a multi-pyridylalkoxide ligand (i.e., 1,3,5-triarylbenzene motif appended with alkoxide and pyridine donors) [107] (Figure 7A,B). By treating the $\mathrm{Mn}_{3} \mathrm{CaO}_{4}$-cluster with $\mathrm{Ln}\left(\mathrm{CF}_{3} \mathrm{SO}_{3}\right)_{3}\left(\mathrm{Ln}=\mathrm{La}^{3+}, \mathrm{Ce}^{3+}, \mathrm{Gd}^{3+}\right.$, etc), they isolated different $\mathrm{Mn}_{3} \mathrm{LnO}_{4}$-clusters, and observed a linear correlation between the redox potential of the cluster and the $\mathrm{pKa}$ of the lanthanide metal ions [109]. The same group reported a series of analogues or derivatives [110] for the artificial $\mathrm{Mn}_{3} \mathrm{CaAgO}_{4}$-complex [111] (Figure 7C,D). 


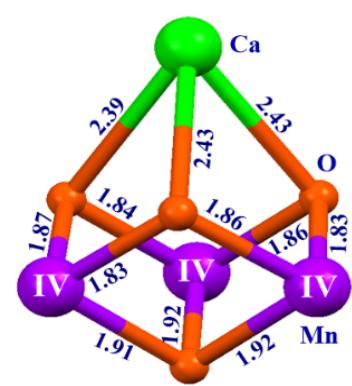

(A)

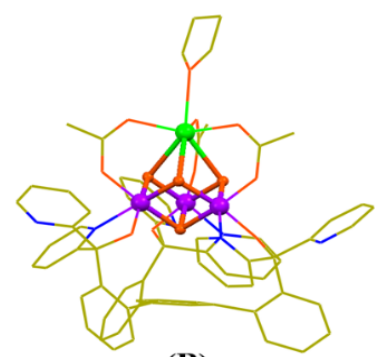

(B)

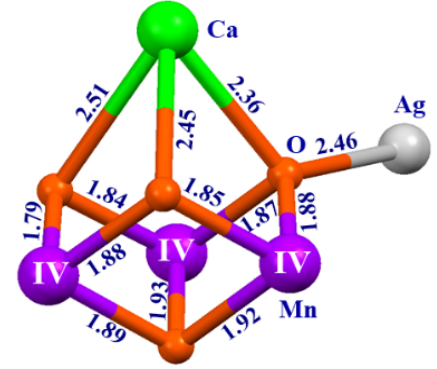

(C)

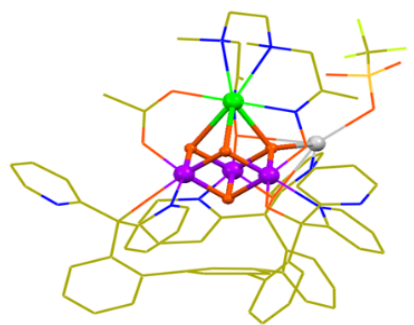

(D)

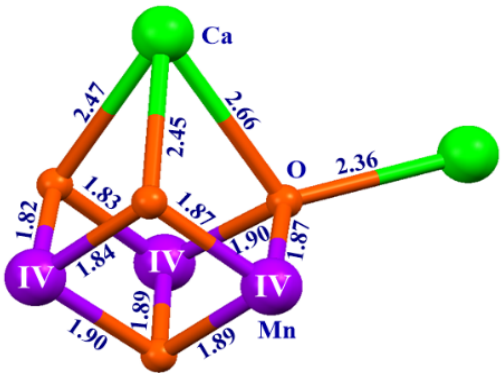

(E)

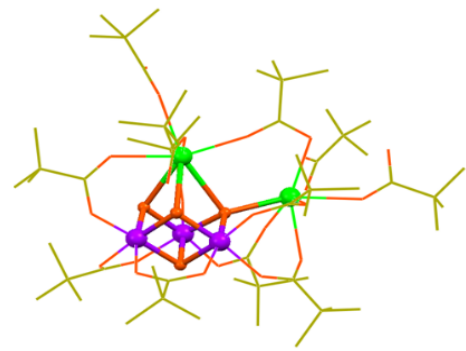

(F)

Figure 7. Structures of artificial complexes containing the $\mathrm{Mn}_{3} \mathrm{CaO}_{4}$ cubane. (A) Core structure of the $\mathrm{Mn}_{3} \mathrm{CaO}_{4}$-complex [107]. (B) Whole structure of the $\mathrm{Mn}_{3} \mathrm{CaO}_{4}$-complex [107]. (C) Core structure of the Mn3CaAgO4-complex [111]. (D) Whole structure of the $\mathrm{Mn}_{3} \mathrm{CaAgO}_{4}$-complex [111]. (E) Core structure of the $\mathrm{Mn}_{3} \mathrm{Ca}_{2} \mathrm{O}_{4}$-complex [112]. (F) Whole structure of the $\mathrm{Mn}_{3} \mathrm{Ca}_{2} \mathrm{O}_{4}$-complex [112]. Distances are given in $\AA$ units. $\mathrm{Mn}, \mathrm{Ca}, \mathrm{Ag}, \mathrm{O}, \mathrm{N}, \mathrm{F}, \mathrm{S}$, and $\mathrm{C}$ are shown in purple, green, gray, orange, blue, green yellow, bright yellow, and yellow, respectively. For clarity, all hydrogen atoms are not shown.

In 2012, Christou's group reported the $\mathrm{Mn}_{3} \mathrm{Ca}_{2} \mathrm{O}_{4}$-complex with one $\mathrm{Ca}^{2+}$ attached to the $\mathrm{Mn}_{3} \mathrm{CaO}_{4}$ cubane [112] (Figure 7E,F). Distinct from previous $\mathrm{Mn}_{3} \mathrm{CaO}_{4}$-complexes and its derivatives, the peripheral ligands of the $\mathrm{Mn}_{3} \mathrm{Ca}_{2} \mathrm{O}_{4}$-complex are pivalic anions or neutral pivalic acid, which closely mimics the peripheral carboxylate ligands of the OEC in PSII. In these artificial complexes, all the manganese ions are in an IV oxidation state, and the typical bond lengths for $\mathrm{Mn}-\mathrm{O}$ and $\mathrm{Ca}-\mathrm{O}$ range from 1.8-1.9 $\AA$ to $2.4-2.7 \AA$, respectively. The distances of the Mn ... Mn and Mn ... Ca range from $2.7-2.8 \AA$ to $3.2-3.5 \AA$, respectively.

In 2014, we reported a heterometallic cluster containing two $\mathrm{Mn}^{\mathrm{IV}_{3}} \mathrm{SrO}_{4}$-clusters linked by one $\mu_{2}$-oxide bridge [113], which mimics the three types of oxide bridges ( $\mu_{2}$-oxide, $\mu_{3}$-oxide, and $\mu_{4}$-oxide) and the $\mathrm{Mn}_{3} \mathrm{SrO}_{4}$ cubane of the $\mathrm{Sr}^{2+}$-containing OEC [30] at the same time (Figure 8).

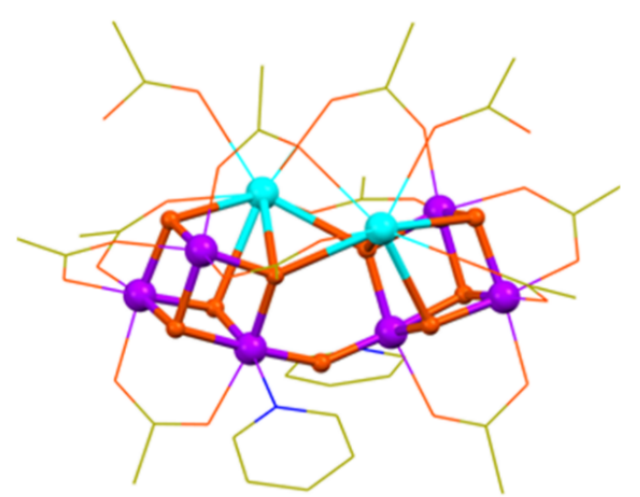

(A)

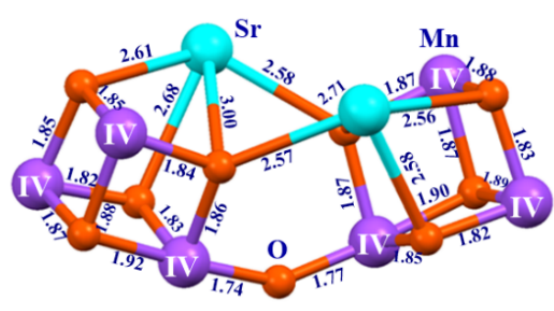

(B)

Figure 8. Structure of the $\mathrm{Mn}_{6} \mathrm{Sr}_{2} \mathrm{O}_{9}$-complex [113]. (A) Whole structure of the $\mathrm{Mn}_{6} \mathrm{Sr}_{2} \mathrm{O}_{9}$-complex. (B) Core structure of the $\mathrm{Mn}_{6} \mathrm{Sr}_{2} \mathrm{O}_{9}$-complex. $\mathrm{Mn}, \mathrm{Sr}, \mathrm{O}, \mathrm{N}$, and $\mathrm{C}$ are shown in purple, cyan, orange, blue, and yellow, respectively. For clarity, all the methyl groups and hydrogen atoms are not shown. 
It should be pointed out that, even though all complexes shown in Figures 7 and 8 have mimicked some key structural motifs of the $\mathrm{Mn}_{3} \mathrm{CaO}_{4}$ or $\mathrm{Mn}_{3} \mathrm{SrO}_{4}$ cubane in the OEC, until recently, it remains a great challenge to synthesize the entire $\mathrm{Mn}_{4} \mathrm{Ca}$-cluster with similar ligands, as seen in the OEC of PSII.

\section{Closer Mimicking of the OEC}

Inspired by the evolution of the OEC [114] and assembly processes of the OEC in PSII [115-117], in 2015, we successfully prepared the first artificial $\mathrm{Mn}_{4} \mathrm{CaO}_{4}$-cluster [118] (Figure 9 C,D), which was synthesized through a two-step procedure using inexpensive commercial chemicals. The first step was to synthesize a precursor through a reaction of $\mathrm{Bu}_{4}{ }_{4} \mathrm{NMnO}_{4}\left(\mathrm{Bu}^{\mathrm{n}}=\mathrm{n}\right.$-butyl), $\mathrm{Mn}\left(\mathrm{CH}_{3} \mathrm{CO}_{2}\right)_{2} \cdot\left(\mathrm{H}_{2} \mathrm{O}\right)_{4}$, and $\mathrm{Ca}\left(\mathrm{CH}_{3} \mathrm{CO}_{2}\right)_{2} \cdot \mathrm{H}_{2} \mathrm{O}$ (molar ratio of 4:1:1) in boiling acetonitrile in the presence of an excess of pivalic acid. The second step was to treat the precursor with organic base (pyridine) in ethyl acetate, which leads to the formation of a final product. We have found that both the acetonitrile solvent and pivalic acid are crucial for the formation of the final product, and the replacements of them by other organic solvents (e.g., THF, $\mathrm{CH}_{3} \mathrm{OH}$ ) and/or organic acids (e.g., acetic acid and propionic acid) lead to failing to prepare the $\mathrm{Mn}_{4} \mathrm{CaO}_{4}$-complex.

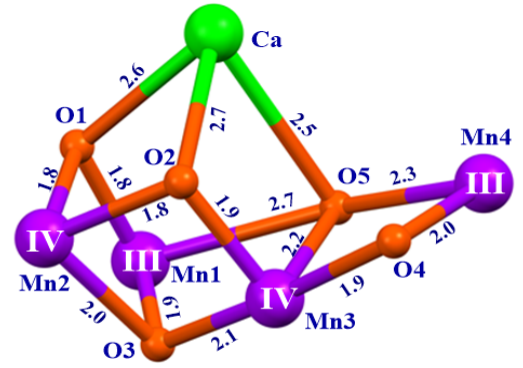

(A)

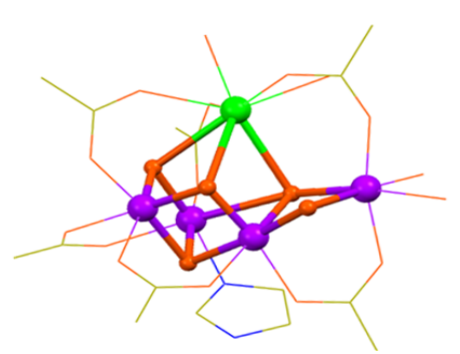

(B)

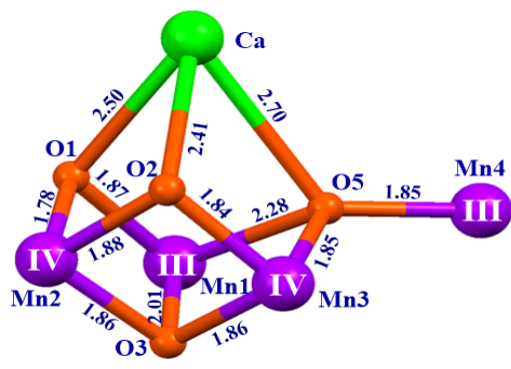

(C)

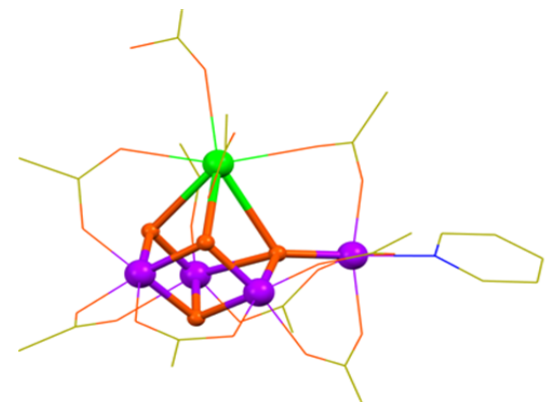

(D)

Figure 9. Structures of the natural OEC [50] (A,B) and the artificial $\mathrm{Mn}_{4}$ Ca-cluster [118] (C,D). Distances are given in $\AA$ units. Mn, Ca, O, N and C are shown in purple, green, orange, blue, and yellow, respectively. The oxidation states of the four manganese ions in $\mathbf{A}$ are directly taken from the previous suggestion [50], which are different from the BVS calculations listed in Table 1. For clarity, all the methyl groups and hydrogen atoms are not shown.

The artificial $\mathrm{Mn}_{4} \mathrm{CaO}_{4}$-complex contains a $\mathrm{Mn}_{3} \mathrm{CaO}_{4}$ cubane attached with a dangler $\mathrm{Mn}$ ion, which forms an asymmetric $\mathrm{Mn}_{4} \mathrm{CaO}_{4}$-core structure. This is exactly the same as the OEC structure proposed by Ferreira et al. in 2004 [42]. The surrounding ligands of the $\mathrm{Mn}_{4} \mathrm{CaO}_{4}$-cluster are provided by eight $\left(\mathrm{CH}_{3}\right)_{3} \mathrm{CCO}_{2}{ }^{-}$anions and three exchangeable neutral ligands (two pivalic acid and one pyridine molecules), which are similar to the peripheral ligands of the OEC (Figure 9B).

It should be pointed out that the structure of the artificial $\mathrm{Mn}_{4} \mathrm{CaO}_{4}$-cluster is well-defined and the effect from the $\mathrm{X}$-ray radiation reduction is limited mainly due to the absence of water as solvent in the crystal of the artificial $\mathrm{Mn}_{4} \mathrm{CaO}_{4}$-complex. BVS calculations have clearly shown that the oxidation states of the four manganese ions of the artificial $\mathrm{Mn}_{4} \mathrm{CaO}_{4}$-complex are (III, III, IV, IV), which are 
essentially the same as that proposed for the OEC in the $\mathrm{S}_{1}$ state in the high-oxidation paradigm (Figure 1).

The similarity between the artificial $\mathrm{Mn}_{4} \mathrm{CaO}_{4}$-cluster and the natural $\mathrm{OEC}$ was further supported by the observation of four redox transitions revealed by cyclic voltammogram (CV) measurements (Figure 10). The redox potential of $\sim 0.8 \mathrm{eV}$ (vs. NHE) for the $\mathrm{S}_{1} \rightarrow \mathrm{S}_{2}$ transition of artificial $\mathrm{Mn}_{4} \mathrm{CaO}_{4}$-complex is close to the estimated potential of the corresponding OEC redox transition $(\geq 0.9 \mathrm{~V})[4,96]$, but it is remarkably different from that of the previously $\mathrm{Mn}_{3} \mathrm{CaO}_{4}$-complex without a dangling Mn ion [107]. This result indicates that the dangler manganese ion could play a crucial role in tuning the redox potential of the $\mathrm{Mn}_{4} \mathrm{CaO}_{4}$-cluster.

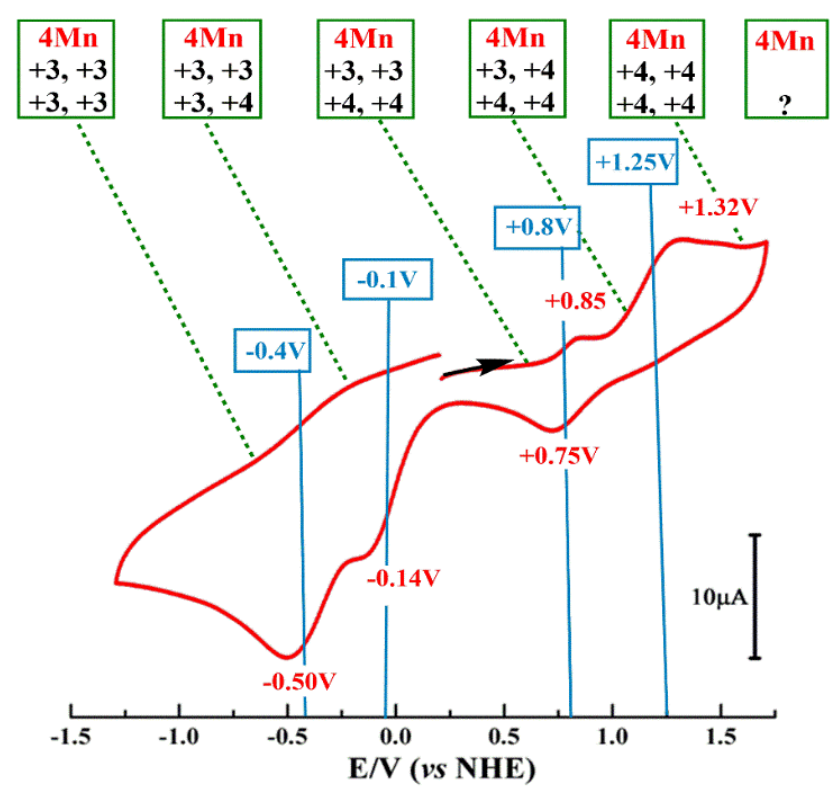

Figure 10. Cyclic voltammogram (CV) of the artificial $\mathrm{Mn}_{4} \mathrm{CaO}_{4}$-complex [118]. Peak positions of CV waves are in red and estimated midpoint potentials are in blue. The likely oxidation states of the four $\mathrm{Mn}$ ions in various oxidation states of artificial complex are indicated using black numbers.

Moreover, the one-electron oxidation of the artificial $\mathrm{Mn}_{4} \mathrm{CaO}_{4}$-complex gave rise to two distinct electron paramagnetic resonance (EPR) signals $(g=4.9$ and $g=2.0$ ) [118] (Figure 11), which is similar to the $g \approx 4$ and $g=2.0$ EPR signals observed in PSII for the OEC in the $S_{2}$ state $[16,119-123]$. In the field of photosynthetic research, the latter two EPR signals have been considered as fingerprint spectroscopic characteristics to evaluate the structure and function of the OEC. Therefore, the experimental observation of two EPR signals suggested that the artificial $\mathrm{Mn}_{4} \mathrm{CaO}_{4}$-cluster would have a similar electronic structure as that of the OEC in the biological system.

The origin of the $g=2$ and $g \approx 4$ EPR signals in both natural and artificial $\mathrm{Mn}_{4} \mathrm{Ca}$-clusters have been theoretically investigated recently $[71,72,100,120,124-128]$. It was suggested that the two EPR signals could be raised from two different conformations of the OEC in the $S_{2}$ state $[72,120,125]$, and the $g=2$ EPR signal could correspond to the structure with an open $\mathrm{Mn}_{3} \mathrm{CaO}_{4}$ cubane, while the $g \approx 4$ EPR signal may be raised with a closed $\mathrm{Mn}_{3} \mathrm{CaO}_{4}$ cubane. Narzi et al. suggested that the conversion between these two conformations could be crucial for the function of the OEC [71]. On the contrary, Corry and O'Malley suggested that the high-spin $(g \approx 4)$ and low spin $(g=2)$ EPR signals could be raised from the same conformation of the OEC, but have different protonation states of $\mathrm{O} 4$ (i.e., $\mu_{2}-\mathrm{O}^{2-}$ or $\mu_{2}-\mathrm{OH}^{-}$) in the $\mathrm{Mn}_{4} \mathrm{CaO}_{5}$-cluster [125]. Pushkar et al. recently proposed that the high spin $(g=4)$ EPR signal could be raised from the early binding of the substrate oxygen to the five-coordinate $\mathrm{Mn} 1$ ion in the $\mathrm{S}_{2}$ state [128]. Some theoretical studies on the two EPR signals of the artificial $\mathrm{Mn}_{4} \mathrm{CaO}_{4}$-cluster have been reported [126,127], while the real origin of these signals is still elusive. So far, the origin of these two EPR signals observed in both a natural and artificial 
$\mathrm{Mn}_{4} \mathrm{Ca}$-cluster is still an open question $[123,124,128,129]$. Considering the lack of $\mu_{2}$-oxo (O4) in the reported artificial $\mathrm{Mn}_{4} \mathrm{CaO}_{4}$-cluster resulting in a large and significant change in the orientation of dangling $\mathrm{Mn} 4$, as compared to the $\mathrm{Mn}_{4} \mathrm{CaO}_{5}$-cluster in OEC, we suggest that the precise mimic of the OEC with the presence of the $\mu_{2}$-oxo $(\mathrm{O} 4)$ is pressingly needed in the future. This would provide crucial information for the entities and process of the biological $\mathrm{Mn}_{4} \mathrm{CaO}_{5}$-cluster in PSII.

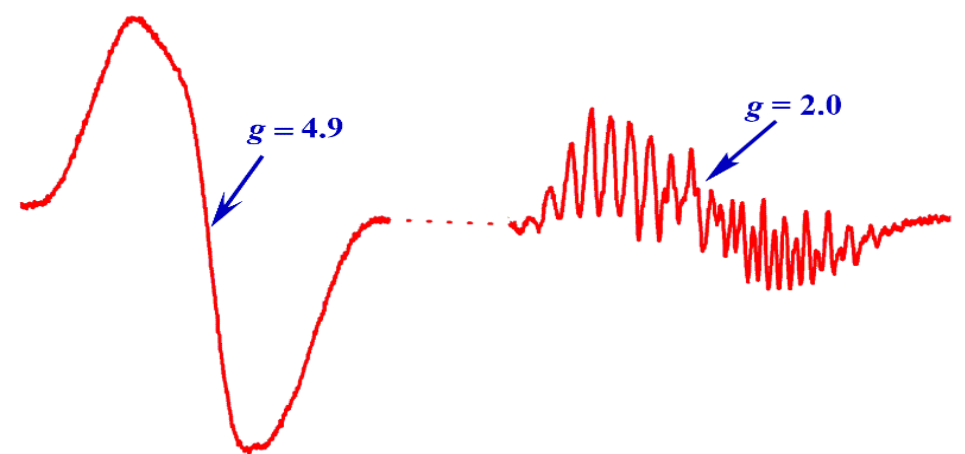

Artificial $\mathrm{Mn}_{4} \mathrm{CaO}_{4}$-cluster

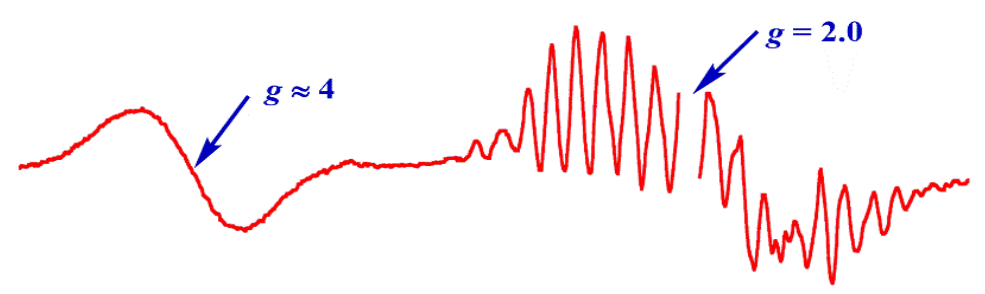

Natural $\mathrm{Mn}_{4} \mathrm{CaO}_{5}$-cluster

Figure 11. Electron paramagnetic resonance (EPR) spectra for the artificial $\mathrm{Mn}_{4} \mathrm{CaO}_{4}$-cluster [118] (top) and natural $\mathrm{Mn}_{4} \mathrm{CaO}_{5}$-cluster [16] (below) in the $\mathrm{S}_{2}$ state.

Considering the close mimicking of both the geometric and electronic structures as well as the redox properties of the OEC, we expect that the artificial $\mathrm{Mn}_{4} \mathrm{CaO}_{4}$-cluster should be able to serve as a catalyst for the water-splitting reaction. A remarkable catalytic current was observed during the $\mathrm{CV}$ measurement in the presence of an artificial $\mathrm{Mn}_{4} \mathrm{CaO}_{4}$-complex and $1 \%$ water in acetonitrile [118] (Figure 12). The artificial $\mathrm{Mn}_{4} \mathrm{CaO}_{4}$-complexes can also catalyze an oxygen-evolving reaction efficiently by using $\left(\mathrm{CH}_{3}\right)_{3} \mathrm{COOH}$ (tert-butyl hydroperoxide) as an oxidant in acetonitrile [130]. However, it should be pointed out that the artificial complex is very sensitive to the experimental conditions. Quantification of the catalytic reaction is difficult due to the rapid degradation of the catalyst in the presence of water in solution. Particularly, the calcium ion in the artificial cluster has been found to be easily dissociated in the presence of water, which leads to the formation of multi-manganese complexes.

To improve the stability of the artificial $\mathrm{Mn}_{4} \mathrm{CaO}_{4}$-cluster, we have recently prepared two new $\mathrm{Mn}_{4} \mathrm{CaO}_{4}$-clusters with an exchangeable solvent known as acetonitrile or $\mathrm{N}, \mathrm{N}$-dimethylformamide (DMF) [58] on the calcium, as shown in Figure 13. Remarkably, the replacement of one or two ligands on the calcium by organic solvent molecules does not modify the core structure and valences of the four manganese ions as well as the main peripheral environmental ligands. More importantly, these new $\mathrm{Mn}_{4} \mathrm{CaO}_{4}$-clusters become more stable in the polar solvent, which may provide a great opportunity to investigate the catalytic activity of the artificial $\mathrm{Mn}_{4} \mathrm{CaO}_{4}$-cluster in the future. 


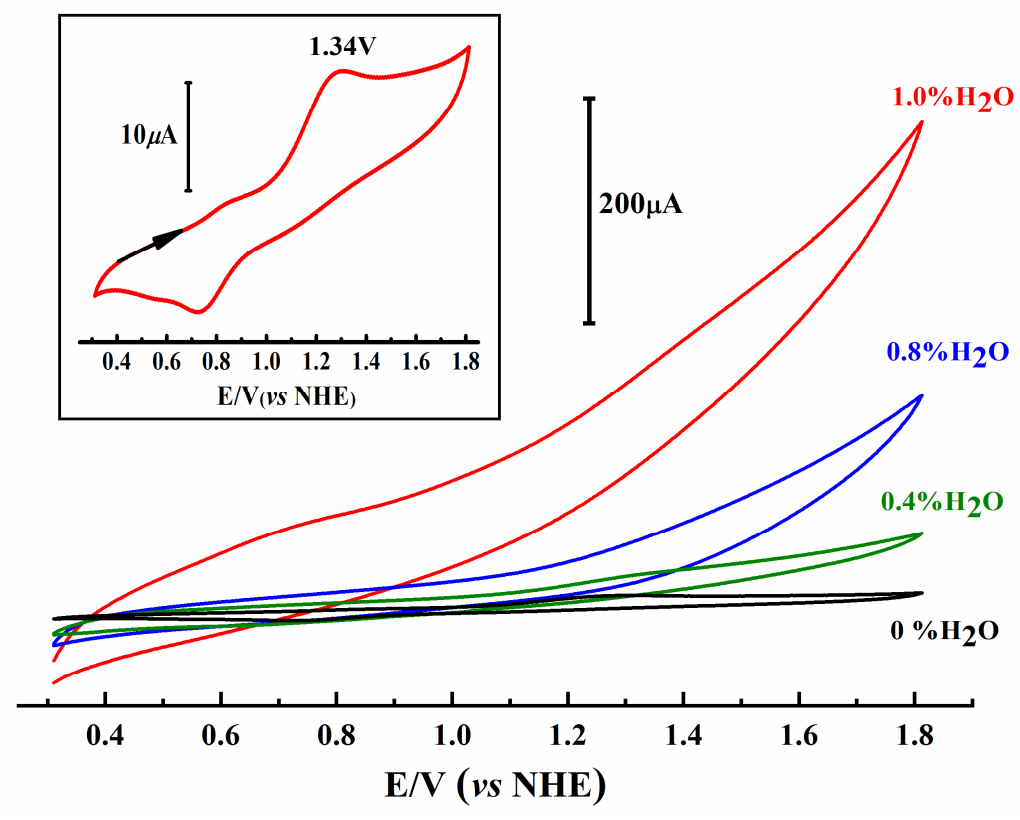

Figure 12. Catalytic properties of the artificial $\mathrm{Mn}_{4} \mathrm{CaO}_{4}$-cluster [118]. Cyclic voltammogram (CV) measurement of the artificial $\mathrm{Mn}_{4} \mathrm{CaO}_{4}$-complex in acetonitrile with different amounts of $\mathrm{H}_{2} \mathrm{O}$. The inset shows the $\mathrm{CV}$ without $\mathrm{H}_{2} \mathrm{O}\left(0 \% \mathrm{H}_{2} \mathrm{O}\right)$.

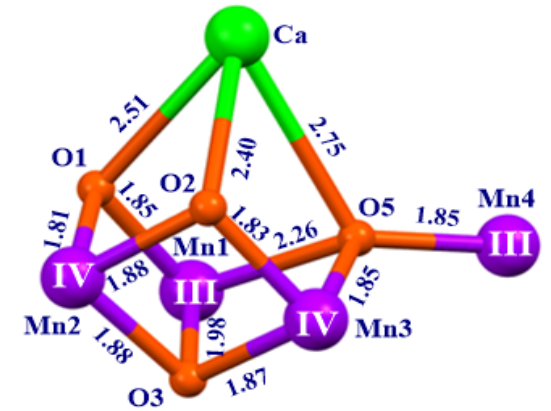

(A)

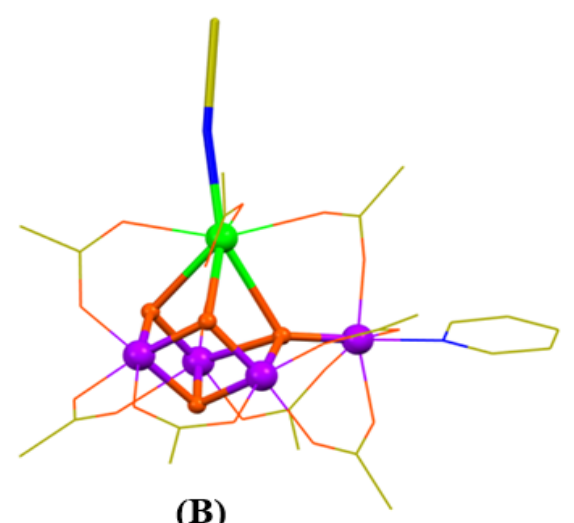

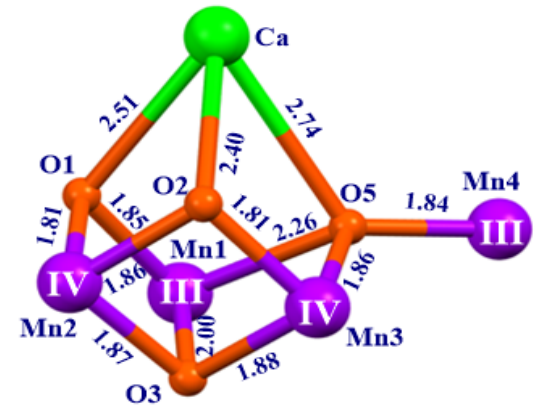

(C)

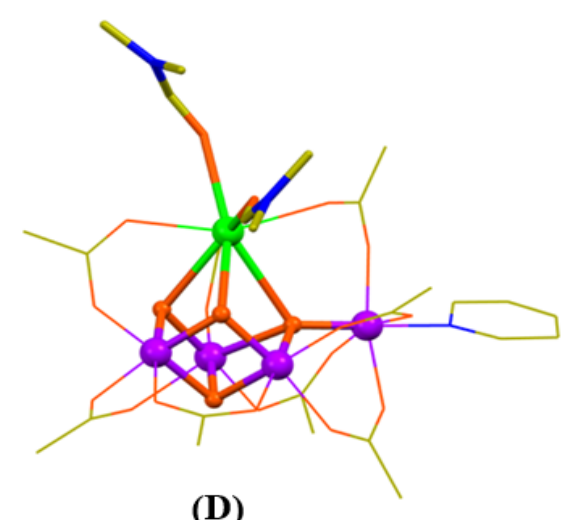

(D)

Figure 13. Crystal structures of two new artificial $\mathrm{Mn}_{4} \mathrm{CaO}_{4}$-complexes with an exchangeable solvent, acetonitrile (A, B) and DMF (C, D) on the calcium [58]. Mn, Ca, O, N, and C are shown in purple, green, orange, blue, and yellow, respectively. Distances are given in $\AA$. The oxidation states of four manganese ions are obtained by the BVS calculation. For clarity, all the methyl groups in pivalic groups and hydrogen atoms are omitted. 


\section{Implications for the Mechanism of the Water-Splitting Reaction in OEC}

Artificial $\mathrm{Mn}_{4} \mathrm{CaO}_{4}$-clusters shown in Figures 9 and 13 have mimicked the main structural motifs of the OEC, which could provide distinct chemical insight into understanding the principle of the OEC [127,131,132]. First, the successful isolation of different artificial $\mathrm{Mn}_{4} \mathrm{CaO}_{4}$-complexes demonstrates that the $\mathrm{Mn}_{4} \mathrm{CaO}_{4}$-cluster is thermodynamically stable, which supports the proposal that the $\mathrm{Mn}_{4} \mathrm{CaO}_{4}$-cluster could be an evolutionary origin of the natural OEC by Barber [133]. Second, from the structure of an artificial $\mathrm{Mn}_{4} \mathrm{CaO}_{4}$-cluster, we can clearly see that the $\mu_{4}-\mathrm{O}^{2-}$ bridge (O5) is tightly bound to four metal ions (one calcium and three manganese ions). This is a position less prone to be removed or replaced, which indicates that the similar $\mu_{4}-\mathrm{O}^{2-}$ bridge (O5) in OEC could not be directly involved in serving as an oxygen source to form the O-O bond, as proposed recently $[6,52,66,67,78]$. Kawashima et al. have recently proposed that the $\mu_{2}-\mathrm{O}^{2-}$ bridge (O4) in OEC (Figure 4) may play a role as the substrate binding site to form the $\mathrm{O}-\mathrm{O}$ bond [79]. In this proposal and some previous suggestions [77,80,82], the $\mathrm{Mn}_{4} \mathrm{CaO}_{4}$ fragment does not undertake significant changes during the water-splitting reaction, which is consistent with the isolation of the stable artificial $\mathrm{Mn}_{4} \mathrm{CaO}_{4}$-clusters described in this case. It should be pointed out that the $\mu_{2}-\mathrm{O}^{2-}(\mathrm{O} 4)$ in OEC is absent in the artificial $\mathrm{Mn}_{4} \mathrm{CaO}_{4}$-cluster $[100,134]$, which is replaced by a bridging carboxyl group in the latter. Clearly, the future investigation of this missing $\mu_{2}-\mathrm{O}^{2-}$ bridge in an artificial $\mathrm{Mn}_{4} \mathrm{Ca}$-cluster may provide new insights into the mechanism for the $\mathrm{O}-\mathrm{O}$ bond formation during the OEC turnover.

\section{Conclusions}

In summary, the crystallographic studies of PSII have revealed that the OEC is composed by an asymmetric $\mathrm{Mn}_{4} \mathrm{CaO}_{5}$-cluster. Although extensive investigations have been carried out on both the natural and artificial OEC in the last three decades, the detailed mechanism for the water-splitting reaction in a natural system is still elusive due to the complexity of the large protein environment and structural uncertainty of the OEC in different S-states during the catalytic turnover. A long-standing goal in science seeks to understand the structure-function relationship of the OEC and develop efficient man-made water-splitting catalysts in artificial photosynthesis. Recently, different model complexes have been synthesized to mimic the OEC in the laboratory where the artificial $\mathrm{Mn}_{4} \mathrm{CaO}_{4}$-cluster closely mimics both the geometric and electronic structures of the OEC. This artificial $\mathrm{Mn}_{4} \mathrm{CaO}_{4}$-cluster provides a rational chemical model to investigate the structure-function relationship of the OEC, and also sheds new insights into the mechanism of the water-splitting reaction in natural photosynthesis. These recent advances in the mimicking of the OEC may help develop efficient man-made catalysts for the water-splitting reaction by using earth-abundant and non-toxic chemical elements in artificial photosynthesis in the future.

Funding: The National Key Research \& Development Program of China (No. 2017YFA0503704), the Strategic Priority Research Program of Chinese Academy of Sciences (No. XDA21010212, XDB17030600), and the National Natural Science Foundation of China (No. 31770258; 91961203) supported this work.

Conflicts of Interest: The authors declare no conflict of interest.

\section{References}

1. Shen, J.R. The structure of photosystem II and the mechanism of water oxidation in photosynthesis. Аnпu. Rev. Plant Biol. 2015, 66, 23-48. [CrossRef] [PubMed]

2. Junge, W. Oxygenic photosynthesis: History, status and perspective. Q. Rev. Biophys. 2019, 52, e1. [CrossRef] [PubMed]

3. Barber, J. Photosynthetic energy conversion: Natural and artificial. Chem. Soc. Rev. 2009, 38, 185-196. [CrossRef] [PubMed]

4. Dau, H.; Zaharieva, I. Principles, efficiency and blueprint character of solar-energy conversion in photosynthetic water oxidation. Acc. Chem. Res. 2009, 42, 1861-1870. [CrossRef] [PubMed] 
5. Nelson, N.; Yocum, C.F. Structure and function of photosystem I and II. Annu. Rev. Plant Biol. 2006, 57, 521-565. [CrossRef]

6. Lubitz, W.; Chrysina, M.; Cox, N. Water oxidation in photosystem II. Photosyn. Res. 2019, 142, $105-125$. [CrossRef]

7. Pantazis, D.A. Missing pieces in the puzzle of biological water oxidation. ACS Catal. 2018, 8, 9477-9507. [CrossRef]

8. Cardona, T.; Sedoud, A.; Cox, N.; Rutherford, A.W. Charge separation in Photosystem II: A comparative and evolutionary overview. Biochim. Biophys. Acta 2012, 1817, 26-43. [CrossRef]

9. Zhang, B.; Sun, L. Artificial photosynthesis: Opportunities and challenges of molecular catalysts. Chem. Soc. Rev. 2019, 48, 2216-2264. [CrossRef]

10. Matheu, R.; Garrido-Barros, P.; Gil-Sepulcre, M.; Ertem, M.Z.; Sala, X.; Gimbert-Suriñach, C.; Llobet, A. The development of molecular water oxidation catalysts. Nat. Rev. Chem. 2019, 3, 331-341. [CrossRef]

11. Kok, B.; Forbush, B.; McGloin, M. Cooperation of charges in photosynthetic $\mathrm{O}_{2}$ evolution. I. A linear four step mechanism. Photochem. Photobiol. 1970, 11, 457-475. [CrossRef] [PubMed]

12. Dau, H.; Haumann, M. Eight steps preceding $\mathrm{O}-\mathrm{O}$ bond formation in oxygenic photosynthesis-A basic reaction cycle of the Photosystem II manganese complex. Biochim. Biophys. Acta 2007, 1767, 472-483. [CrossRef] [PubMed]

13. Debus, R.J. The manganese and calcium ions of photosynthetic oxygen evolution. Biochim. Biophys. Acta 1992, 1102, 269-352. [CrossRef]

14. Debus, R.J. Amino acid residues that modulate the properties of tyrosine $\mathrm{Y}_{Z}$ and the manganese cluster in the water oxidizing complex of photosystem II. Biochim. Biophys. Acta 2001, 1503, 164-186. [CrossRef]

15. Diner, B.A. Amino acid residues involved in the coordination and assembly of the manganese cluster of photosystem II. Proton-coupled electron transport of the redox-active tyrosines and its relationship to water oxidation. Biochim. Biophys. Acta 2001, 1503, 147-163. [CrossRef]

16. Peloquin, J.M.; Britt, R.D. EPR/ENDOR characterization of the physical and electronic structure of the OEC Mn-cluster. Biochim. Biophys. Acta 2001, 1503, 96-111. [CrossRef]

17. Krewald, V.; Retegan, M.; Cox, N.; Messinger, J.; Lubitz, W.; DeBeer, S.; Neese, F.; Pantazis, D.A. Metal oxidation states in biological water splitting. Chem. Sci. 2015, 6, 1676-1695. [CrossRef]

18. Yano, J.; Yachandra, V.K. $\mathrm{Mn}_{4}$ Ca-cluster in photosynthesis: Where and how water is oxidized to dioxygen. Chem. Rev. 2014, 114, 4175-4205. [CrossRef]

19. Dau, H.; Haumann, M. The manganese complex of photosystem II in its reaction cycle-Basic framework and possible realization at the atomic level. Coord. Chem. Rev. 2008, 252, 273-295. [CrossRef]

20. Dau, H.; Grundmeier, A.; Loja, P.; Haumann, M. On the structure of the manganese complex of photosystem II: Extended-range EXAFS data and specific atomic-resolution models for four S-states. Philos. Trans. R. Soc. Lond. B 2008, 363, 1237-1244. [CrossRef]

21. Sauer, K.; Yano, J.; Yachandra, V.K. X-ray spectroscopy of the photosynthetic oxygen-evolving complex. Coord. Chem. Rev. 2008, 252, 318-335. [CrossRef] [PubMed]

22. Zheng, M.; Dismukes, G.C. Orbital configuration of the valence electrons, ligand field symmetry, and manganese oxidation states of the photosynthetic water oxidizing complex: Analysis of the $\mathrm{S}_{2}$ state multiline EPR signals. Inorg. Chem. 1996, 35, 3307-3319. [CrossRef] [PubMed]

23. Pace, R.J.; Jin, L.; Stranger, R. What spectroscopy reveals concerning the Mn oxidation levels in the oxygen evolving complex of photosystem II: X-ray to near infra-red. Dalton Trans. 2012, 41, 11145-11160. [CrossRef] [PubMed]

24. Jin, L.; Smith, P.; Noble, C.J.; Stranger, R.; Hanson, G.R.; Pace, R.J. Electronic structure of the oxygen evolving complex in photosystem II, as revealed by ${ }^{55} \mathrm{Mn}$ Davies ENDOR studies at $2.5 \mathrm{~K}$. Phys. Chem. Chem. Phys. 2014, 16, 7799-7812. [CrossRef]

25. Petrie, S.; Stranger, R.; Pace, R.J. Explaining the different geometries of the water oxidising complex in the nominal $S_{3}$ state crystal structures of photosystem II at $2.25 \AA$ and $2.35 \AA$. ChemPhysChem 2018, 19, 3296-3309. [CrossRef]

26. Petrie, S.; Pace, R.J.; Stranger, R. Resolving the differences between the $1.9 \AA$ and $1.95 \AA$ crystal structures of photosystem II: A single proton relocation defines two tautomeric forms of the water-oxidizing complex. Angew. Chem. Int. Ed. 2015, 54, 7120-7124. [CrossRef] 
27. Petrie, S.; Stranger, R.; Pace, R.J. Rationalizing the $2.25 \AA$ resolution crystal structure of the water oxidising complex of photosystem II in the $S_{3}$ state. ChemPhysChem 2017, 18, 2924-2931. [CrossRef]

28. van Gorkom, H.J.; Yocum, C.F. The calcium and chloride cofactor. In Photosystem II: The Light-Driven Water: Plastoquinone Oxidoreductase; Wydrzynski, T.J., Satoh, K., Eds.; Springer: Dordrecht, The Netherlands, 2005; pp. 307-328.

29. Yocum, C.F. The calcium and chloride requirements of the $\mathrm{O}_{2}$ evolving complex. Coord. Chem. Rev. 2008, 252, 296-305. [CrossRef]

30. Koua, F.H.M.; Umena, Y.; Kawakami, K.; Shen, J.R. Structure of Sr-substituted photosystem II at $2.1 \AA$ resolution and its implications in the mechanism of water oxidation. Proc. Natl. Acad. Sci. USA 2013, 110, 3889-3894. [CrossRef]

31. Cox, N.; Pantazis, D.A.; Neese, F.; Lubitz, W. Biological water oxidation. Acc. Chem. Res. 2013, 46, 1588-1596. [CrossRef]

32. Siegbahn, P.E.M. Structures and energetics for $\mathrm{O}_{2}$ formation in photosystem II. Acc. Chem. Res. 2009, 42, 1871-1880. [CrossRef] [PubMed]

33. Tommos, C.; Babcock, G.T. Oxygen production in nature: A light-driven metalloradical enzyme process. Acc. Chem. Res. 1998, 31, 18-25. [CrossRef]

34. Cinco, R.M.; Robblee, J.H.; Rompel, A.; Fernandez, C.; Yachandra, V.K.; Sauer, K.; Klein, M.P. Strontium EXAFS reveals the proximity of calcium to the manganese cluster of oxygen-evolving photosystem II. J. Phys. Chem. B 1998, 102, 8248-8256. [CrossRef] [PubMed]

35. Peloquin, J.M.; Campbell, K.A.; Randall, D.W.; Evanchik, M.A.; Pecoraro, V.L.; Armstrong, W.H.; Britt, R.D. ${ }^{55} \mathrm{Mn}$ ENDOR of the $\mathrm{S}_{2}$-state multiline EPR signal of photosystem II: Implications on the structure of the tetranuclear Mn cluster. J. Am. Chem. Soc. 2000, 122, 10926-10942. [CrossRef]

36. Vrettos, J.S.; Limburg, J.; Brudvig, G.W. Mechanism of photosynthetic water oxidation: Combining biophysical studies of photosystem II with inorganic model chemistry. Biochim. Biophys. Acta 2001, 1503, 229-245. [CrossRef]

37. Zhang, C.; Pan, J.; Li, L.; Kuang, T. New structure model of oxygen-evolving center and mechanism for oxygen evolution in photosynthesis. Chin. Sci. Bull. 1999, 44, 2209-2215. [CrossRef]

38. Zhang, C. From natural photosynthesis to artificial photosynthesis. Sci. Sin. Chim. 2016, 46, 1101-1109. [CrossRef]

39. Umena, Y.; Kawakami, K.; Shen, J.R.; Kamiya, N. Crystal structure of oxygen-evolving photosystem II at a resolution of 1.9 ̊. Nature 2011, 473, 55-60. [CrossRef]

40. Zouni, A.; Witt, H.T.; Kern, J.; Fromme, P.; Kraub, N.; Saenger, W.; Orth, P. Crystal structure of photosystem II from Synechococcus elongatus at 3.8̊ resolution. Nature 2001, 409, 739-743. [CrossRef]

41. Kamiya, N.; Shen, J.R. Crystal structure of oxygen-evolving photosystem II from Thermosynechococcus vulcanus at 3.7 ̊̊ resolution. Proc. Natl. Acad. Sci. USA 2003, 100, 98-103. [CrossRef]

42. Ferreira, K.N.; Iverson, T.M.; Maghlaoui, K.; Barber, J.; Iwata, S. Architecture of the photosynthetic oxygen-evolving center. Science 2004, 303, 1831-1838. [CrossRef] [PubMed]

43. Guskov, A.; Kern, J.; Gabdulkhakov, A.; Broser, M.; Zouni, A.; Saenger, W. Cyanobacterial photosystem II at 2.9-Å resolution and the role of quinones, lipids, channels and chloride. Nat. Struct. Mol. Biol. 2009, 16, 334-342. [CrossRef] [PubMed]

44. Hellmich, J.; Bommer, M.; Burkhardt, A.; Ibrahim, M.; Kern, J.; Meents, A.; Müh, F.; Dobbek, H.; Zouni, A. Native-like photosystem II superstructure at $2.44 \AA$ resolution through detergent extraction from the protein crystal. Structure 2014, 22, 1607-1615. [CrossRef] [PubMed]

45. Yano, J.; Kern, J.; Sauer, K.; Latimer, M.J.; Pushkar, Y.; Biesiadka, J.; Loll, B.; Saenger, W.; Messinger, J.; Zouni, A.; et al. Where water is oxidized to dioxygen: Structure of the photosynthetic $\mathrm{Mn}_{4} \mathrm{Ca}$ cluster. Science 2006, 314, 821-825. [CrossRef]

46. Young, I.D.; Ibrahim, M.; Chatterjee, R.; Gul, S.; Fuller, F.D.; Koroidov, S.; Brewster, A.S.; Tran, R.; Alonso-Mori, R.; Kroll, T.; et al. Structure of photosystem II and substrate binding at room temperature. Nature 2016, 540, 453-457. [CrossRef]

47. Yano, J.; Kern, J.; Irrgang, K.D.; Latimer, M.J.; Bergmann, U.; Glatzel, P.; Pushkar, Y.; Biesiadka, J.; Loll, B.; Sauer, K.; et al. X-ray damage to the $\mathrm{Mn}_{4} \mathrm{Ca}$ complex in single crystals of photosystem II: A case study for metalloprotein crystallography. Proc. Natl. Acad. Sci. USA 2005, 102, 12047-12052. [CrossRef] 
48. Grabolle, M.; Haumann, M.; Müller, C.; Liebisch, P.; Dau, H. Rapid loss of structural motifs in the manganese complex of oxygenic photosynthesis by X-ray irradiation at 10-300K. J. Biol. Chem. 2006, 281, 4580-4588. [CrossRef]

49. Askerka, M.; Brudvig, G.W.; Batista, V.S. The $\mathrm{O}_{2}$-evolving complex of photosystem II: Recent insights from quantum mechanics/molecular mechanics (QM/MM), extended X-ray absorption fine structure (EXAFS), and femtosecond X-ray crystallography data. Acc. Chem. Res 2017, 50, 41-48. [CrossRef]

50. Suga, M.; Akita, F.; Hirata, K.; Ueno, G.; Murakami, H.; Nakajima, Y.; Shimizu, T.; Yamashita, K.; Yamamoto, M.; Ago, H.; et al. Native structure of photosystem II at $1.95 \AA$ resolution revealed by a femtosecond X-ray laser. Nature 2015, 517, 99-103. [CrossRef]

51. Suga, M.; Akita, F.; Sugahara, M.; Kubo, M.; Nakajima, Y.; Nakane, T.; Yamashita, K.; Umena, Y.; Nakabayashi, M.; Yamane, T.; et al. Light-induced structural changes and the site of $\mathrm{O}=\mathrm{O}$ bond formation in PSII caught by XFEL. Nature 2017, 543, 131-135. [CrossRef]

52. Suga, M.; Akita, F.; Yamashita, K.; Nakajima, Y.; Ueno, G.; Li, H.; Yamane, T.; Hirata, K.; Umena, Y.; Yonekura, S.; et al. An oxyl/oxo mechanism for oxygen-oxygen coupling in PSII revealed by an x-ray free-electron laser. Science 2019, 366, 334-338. [CrossRef] [PubMed]

53. Kern, J.; Chatterjee, R.; Young, I.D.; Fuller, F.D.; Lassalle, L.; Ibrahim, M.; Gul, S.; Fransson, T.; Brewster, A.S.; Alonso-Mori, R.; et al. Structures of the intermediates of Kok's photosynthetic water oxidation clock. Nature 2018, 563, 421-425. [CrossRef] [PubMed]

54. Tanaka, A.; Fukushima, Y.; Kamiya, N. Two different structures of the oxygen-evolving complex in the same polypeptide frameworks of photosystem II. J. Am. Chem. Soc. 2017, 139, 1718-1721. [CrossRef] [PubMed]

55. Wei, X.; Su, X.; Cao, P.; Liu, X.; Chang, W.; Li, M.; Zhang, X.; Liu, Z. Structure of spinach photosystem II-LHCII supercomplex at 3.2A resolution. Nature 2016, 534, 69-74. [CrossRef]

56. Su, X.; Ma, J.; Wei, X.; Cao, P.; Zhu, D.; Chang, W.; Liu, Z.; Zhang, X.; Li, M. Structure and assembly mechanism of plant $\mathrm{C}_{2} \mathrm{~S}_{2} \mathrm{M}_{2}$-type PSII-LHCII supercomplex. Science 2017, 357, 815-820. [CrossRef]

57. Askerka, M.; Vinyard, D.J.; Wang, J.; Brudvig, G.W.; Batista, V.S. Analysis of the radiation-damage-free X-ray structure of photosystem II in light of EXAFS and QM/MM data. Biochemistry 2015, 54, 1713-1716. [CrossRef]

58. Chen, C.; Chen, Y.; Yao, R.; Li, Y.; Zhang, C. Artificial Mn ${ }_{4}$ Ca clusters with exchangeable solvent molecuels mimicking the oxygen-evolving center in photosynthesis. Angew. Chem. Int. Ed. 2019, 58, 3939-3942. [CrossRef]

59. Chen, C.; Chen, Y.; Zhang, C. Mimicking the oxygen-evolving center in photosystem II. In Oxygen Production and Reduction in Artificial and Natural Systems; Barber, J., Ruban, A.V., Nixon, P.J., Eds.; World Scientific Publishing Co. Pte. Ltd.: Singapore, 2019; pp. 167-189.

60. Pauling, L. The principles determining the structure of complex ionic crystals. J. Am. Chem. Soc. 1929, 51, 1010-1026. [CrossRef]

61. Brown, I.D. Recent developments in the methods and applications of the bond valence model. Chem. Rev. 2009, 109, 6858-6919. [CrossRef]

62. Liu, W.; Thorp, H.H. Bond valence sum analysis of metal-ligand bond lengths in metalloenzymes and model complexes. 2. Refined distances and other enzymes. Inorg. Chem. 1993, 32, 4102-4105. [CrossRef]

63. Gatt, P.; Petrie, S.; Stranger, R.; Pace, R.J. Rationalizing the 1.9 Å crystal structure of photosystem II-A remarkable Jahn-Teller balancing act induced by a single proton transfer. Angew. Chem. Int. Ed. 2012, 51, 12025-12028. [CrossRef]

64. Amin, M.; Badawi, A.; Obayya, S.S. Radiation damage in XFEL: Case study from the oxygen-evolving complex of photosystem II. Sci. Rep. 2016, 6, 36492. [CrossRef] [PubMed]

65. Saito, K.; Ishikita, H. Mechanism of protonation of the over-reduced $\mathrm{Mn}_{4} \mathrm{CaO}_{5}$ cluster in photosystem II. Biochim. Biophys. Acta 2019, 1860, 148059. [CrossRef] [PubMed]

66. Yamaguchi, K.; Shoji, M.; Isobe, H.; Yamanaka, S.; Kawakami, T.; Yamada, S.; Katouda, M.; Nakajima, T. Theory of chemical bonds in metalloenzymes XXI. Possible mechanisms of water oxidation in oxygen evolving complex of photosystem II. Mol. Phys. 2018, 116, 717-745. [CrossRef]

67. Siegbahn, P.E.M. Water oxidation mechanism in photosystem II, including oxidations, proton release pathways, $\mathrm{O}-\mathrm{O}$ bond formation and $\mathrm{O}_{2}$ release. Biochim. Biophys. Acta 2013, 1827, 1003-1019. [CrossRef] [PubMed] 
68. Corry, T.A.; O'Malley, P.J. Evidence of $\mathrm{O}-\mathrm{O}$ bond formation in the final metastable $\mathrm{S}_{3}$ state of nature's water oxidizing complex implying a novel mechanism of water oxidation. J. Phys. Chem. Lett. 2018, 9, 6269-6274. [CrossRef]

69. Beal, N.J.; Corry, T.A.; O'Malley, P.J. A comparison of experimental and broken symmetry density functional theory (BS-DFT) calculated electron paramagnetic resonance (EPR) parameters for intermediates involved in the $S_{2}$ to $S_{3}$ state transition of nature's oxygen evolving complex. J. Phys. Chem. B 2018, 122, 1394-1407. [CrossRef]

70. Pushkar, Y.; Davis, K.M.; Palenik, M.C. Model of the oxygen evolving complex which is highly predisposed to O-O bond formation. J. Phys. Chem. Lett. 2018, 9, 3525-3531. [CrossRef]

71. Narzi, D.; Bovi, D.; Guidoni, L. Pathway for Mn-cluster oxidation by tyrosine-Z in the $\mathrm{S}_{2}$ state of photosystem II. Proc. Natl. Acad. Sci. USA 2014, 111, 8723-8728. [CrossRef]

72. Krewald, V.; Retegan, M.; Neese, F.; Lubitz, W.; Pantazis, D.A.; Cox, N. Spin state as a marker for the structural evolution of nature's water-splitting catalyst. Inorg. Chem. 2016, 55, 488-501. [CrossRef]

73. Pushkar, Y.; Yano, J.; Sauer, K.; Boussac, A.; Yachandra, V.K. Structural changes in the $\mathrm{Mn}_{4} \mathrm{Ca}$ cluster and the mechanism of photosynthetic water splitting. Proc. Natl. Acad. Sci. USA 2008, 105, 1879-1884. [CrossRef]

74. Cox, N.; Retegan, M.; Neese, F.; Pantazis, D.A.; Boussac, A.; Lubitz, W. Electronic structure of the oxygen-evolving complex in photosystem II prior to O-O bond formation. Science 2014, 345, 804-808. [CrossRef]

75. Isobe, H.; Shoji, M.; Suzuki, T.; Shen, J.R.; Yamaguchi, K. Spin, valence, and structural isomerism in the $S_{3}$ state of the oxygen-evolving complex of photosystem II as a manifestation of multimetallic cooperativity. $J$. Chem. Theory Comput. 2019, 15, 2375-2391. [CrossRef] [PubMed]

76. Zhang, B.; Sun, L. Why nature chose the $\mathrm{Mn}_{4} \mathrm{CaO}_{5}$ cluster as water-splitting catalyst in photosystem II: A new hypothesis for the mechanism of O-O bond formation. Dalton Trans. 2018, 47, 14381-14387. [CrossRef]

77. Barber, J. A mechanism for water splitting and oxygen production in photosynthesis. Nat. Plants 2017, 3, 17041. [CrossRef] [PubMed]

78. Britt, R.D.; Marchiori, D.A. Photosystem II, poised for $\mathrm{O}_{2}$ formation. Science 2019, 366, 305-306. [CrossRef]

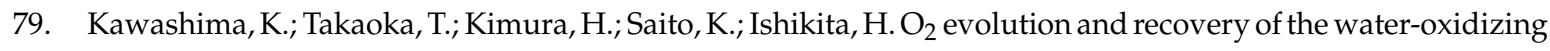
enzyme. Nat. Commun. 2018, 9, 1247. [CrossRef] [PubMed]

80. Vinyard, D.J.; Khan, S.; Brudvig, G.W. Photosynthetic water oxidation: Binding and activation of substrate water for O-O bond formation. Faraday Discuss. 2015, 185, 37-50. [CrossRef]

81. Hoganson, C.W.; Babcock, G.T. A metalloradical mechanism for the generation of oxygen from water in photosynthesis. Science 1997, 277, 1953-1956. [CrossRef] [PubMed]

82. Chen, C.; Zhang, C.; Dong, H.; Zhao, J. Artificial synthetic $\mathrm{Mn}^{\mathrm{IV}}$ Ca-oxido complexes mimic the oxygen-evolving complex in photosystem II. Dalton Trans. 2015, 44, 4431-4435. [CrossRef]

83. Pecoraro, V.L.; Baldwin, M.J.; Caudle, M.T.; Hsieh, W.Y.; Law, N.A. A proposal for water oxidation in photosystem II. Pure Appl. Chem. 1998, 70, 925-929. [CrossRef]

84. Siegbahn, P.E.M. Nucleophilic water attack is not a possible mechanism for O-O bond formation in photosystem II. Proc. Natl. Acad. Sci. USA 2017, 114, 4966-4968. [CrossRef] [PubMed]

85. Zhang, C.; Kuang, T. A new milestone for photosyntehsis. Nat. Sci. Rev. 2018, 5, 444-445. [CrossRef]

86. Haumann, M.; Liebisch, P.; Muller, C.; Barra, M.; Grabolle, M.; Dau, H. Photosynthetic $\mathrm{O}_{2}$ formation tracked by time-resolved x-ray experiments. Science 2005, 310, 1019-1021. [CrossRef] [PubMed]

87. Ishikita, H. Protein environment that facilitates proton transfer and electron transfer in photosystem II. In Oxygen Production and Reduction in Artificial and Natural Systems; Barber, J., Ruban, A.V., Nixon, P.J., Eds.; World Scientific Publishing Co. Pte. Ltd.: Singapore, 2019; pp. 191-208.

88. Zhang, B.; Sun, L. Across the board: Licheng Sun on the mechanism of O-O bond formation in photosystem II. ChemSusChem 2019, 12, 3401-3404. [CrossRef] [PubMed]

89. Isobe, H.; Shoji, M.; Yamanaka, S.; Umena, Y.; Kawakami, K.; Kamiya, N.; Shen, J.R.; Yamaguchi, K. Theoretical illumination of water-inserted structures of the $\mathrm{CaMn}_{4} \mathrm{O}_{5}$-cluster in the $\mathrm{S}_{2}$ and $\mathrm{S}_{3}$ states of oxygen-evolving complex of photosystem II: Full geometry optimizations by B3LYP hybrid density functional. Dalton Trans. 2012, 41, 13727-13740. [CrossRef]

90. Perez-Navarro, M.; Neese, F.; Lubitz, W.; Pantazis, D.A.; Cox, N. Recent developments in biological water oxidation. Curr. Opin. Chem. Biol. 2016, 31, 113-119. [CrossRef] 
91. Zhang, C. The first artificial $\mathrm{Mn}_{4} \mathrm{Ca}$-cluster mimicking the oxygen-evolving center in photosystem II. Sci. Chin. Life Sci. 2015, 58, 816-817. [CrossRef]

92. Mullins, C.S.; Pecoraro, V.L. Reflections on small molecule manganese models that seek to mimic photosynthetic water oxidation chemistry. Coord. Chem. Rev. 2008, 252, 416-443. [CrossRef]

93. Tsui, E.Y.; Kanady, J.S.; Agapie, T. Synthetic cluster models of biological and heterogeneous manganese catalysts for $\mathrm{O}_{2}$ evolution. Inorg. Chem. 2013, 52, 13833-13848. [CrossRef]

94. Kärkäs, M.D.; Verho, O.; Johnston, E.V.; Åkermark, B. Artificial photosynthesis: Molecular systems for catalytic water oxidation. Chem. Rev. 2014, 114, 11863-12001. [CrossRef] [PubMed]

95. Limburg, J.; Vrettos, J.S.; Liable-Sands, L.M.; Rheingold, A.L.; Crabtree, R.H.; Brudvig, G.W. A functional model for O-O bond formation by the $\mathrm{O}_{2}$-evolving complex in photosystem II. Science 1999, 283, 1524-1527. [CrossRef] [PubMed]

96. Vass, I.; Styring, S. pH-dependent charge equilibria between tyrosine-D and the S states in photosystem II. Estimation of relative midpoint redox potentials. Biochemistry 1991, 30, 830-839. [CrossRef] [PubMed]

97. Mukhopadhyay, S.; Mandal, S.K.; Bhaduri, S.; Armstrong, W.H. Manganese clusters with relevance to photosystem II. Chem. Rev. 2004, 104, 3981-4026. [CrossRef]

98. Najafpour, M.M.; Renger, G.; Hołyńska, M.; Moghaddam, A.N.; Aro, E.M.; Carpentier, R.; Nishihara, H.; Eaton-Rye, J.J.; Shen, J.R.; Allakhverdiev, S.I. Manganese compounds as water-oxidizing catalysts: From the natural water-oxidizing complex to nanosized manganese oxide structures. Chem. Rev. 2016, 116, 2886-2936. [CrossRef]

99. Gerey, B.; Goure, E.; Fortage, J.; Pecaut, J.; Collomb, M.N. Manganese-calcium/strontium heterometallic compounds and their relevance for the oxygen-evolving center of photosystem II. Coord. Chem. Rev. 2016, 319, 1-24. [CrossRef]

100. Paul, S.; Neese, F.; Pantazis, D.A. Structural models of the biological oxygen-evolving complex: Achievements, insights, and challenges for biomimicry. Green Chem. 2017, 19, 2309-2325. [CrossRef]

101. Dismukes, G.C.; Brimblecombe, R.; Felton, G.A.N.; Pryadun, R.S.; Sheats, J.E.; Spiccia, L.; Swiegers, G.F. Development of bioinspired $\mathrm{Mn}_{4} \mathrm{O}_{4}$-cubane water oxidation catalysts: Lessons from photosynthesis. Acc. Chem. Res. 2009, 42, 1935-1943. [CrossRef]

102. Chang, W.; Chen, C.; Dong, H.; Zhang, C. Artificial $\mathrm{Mn}_{4}$-oxido complexes mimic the oxygen-evolving center in photosynthesis. Sci. Bull. 2017, 62, 665-668. [CrossRef]

103. Maayan, G.; Gluz, N.; Christou, G. A bioinspired soluble manganese cluster as a water oxidation electrocatalyst with low overpotential. Nat. Cat. 2018, 1, 48-54. [CrossRef]

104. Karlsson, E.A.; Lee, B.L.; Åkermark, T.; Johnston, E.V.; Kärkäs, M.D.; Sun, J.; Hansson, Ő.; Bäckvall, J.E.; Åkermark, B. Photosensitized water oxidation by use of a bioinspired manganese catalyst. Angew. Chem. Int. Ed. 2011, 50, 11715-11718. [CrossRef] [PubMed]

105. Ruettinger, W.F.; Campana, C.; Dismukes, G.C. Synthesis and characterization of $\mathrm{Mn}_{4} \mathrm{O}_{4} \mathrm{~L}_{6}$ complexes with cubane-like core structure: A new class of models of the active site of the photosynthetic water oxidase. J. Am. Chem. Soc. 1997, 119, 6670-6671. [CrossRef]

106. Chakov, N.E.; Abboud, K.A.; Zakharov, L.N.; Rheingold, A.L.; Hendrickson, D.N.; Christou, G. Reaction of $\left[\mathrm{Mn}_{12} \mathrm{O}_{12}\left(\mathrm{O}_{2} \mathrm{CR}\right)_{16}\left(\mathrm{H}_{2} \mathrm{O}\right)_{4}\right]$ single-molecule magnets with non-carboxylate ligands. Polyhedron 2003, 22, 1759-1763. [CrossRef]

107. Kanady, J.S.; Tsui, E.Y.; Day, M.W.; Agapie, T. A synthetic model of the $\mathrm{Mn}_{3}$ Ca subsite of the oxygen-evolving complex in photosystem II. Science 2011, 333, 733-736. [CrossRef] [PubMed]

108. Chakov, N.E.; Thuijs, A.E.; Wernsdorfer, W.; Rheingold, A.L.; Abboud, K.A.; Christou, G. Unusual Mn(III/IV) 4 cubane and $\mathrm{Mn}(\mathrm{III})_{16} \mathrm{M}_{4}(\mathrm{M}=\mathrm{Ca}, \mathrm{Sr})$ looplike clusters from the use of dimethylarsinic acid. Inorg. Chem. 2016, 55, 8468-8477. [CrossRef]

109. Lin, P.H.; Takase, M.K.; Agapie, T. Investigations of the effect of the non-manganese metal in heterometallic-oxido cluster models of the oxygen evolving complex of photosystem II: Lanthanides as substitutes for calcium. Inorg. Chem. 2015, 54, 59-64. [CrossRef]

110. Tsui, E.Y.; Agapie, T. Reduction potentials of heterometallic manganese-oxido cubane complexes modulated by redox-inactive metals. Proc. Natl. Acad. Sci. USA 2013, 110, 10084-10088. [CrossRef] 
111. Kanady, J.S.; Lin, P.H.; Carsch, K.M.; Nielsen, R.J.; Takase, M.K.; Goddard, W.A.; Agapie, T. Toward models for the full oxygen-evolving complex of photosystem II by ligand coordination to lower the symmetry of the $\mathrm{Mn}_{3} \mathrm{CaO}_{4}$ cubane: Demonstration that electronic effects facilitate binding of a fifth metal. J. Am. Chem. Soc. 2014, 136, 14373-14376. [CrossRef]

112. Mukherjee, S.; Stull, J.A.; Yano, J.; Stamatatos, T.C.; Pringouri, K.; Stich, T.A.; Abboud, K.A.; Britt, R.D.; Yachandra, V.K.; Christou, G. Synthetic model of the asymmetric $\left[\mathrm{Mn}_{3} \mathrm{CaO}_{4}\right]$ cubane core of the oxygen-evolving complex of photosystem II. Proc. Natl. Acad. Sci. USA 2012, 109, 2257-2262. [CrossRef]

113. Chen, C.; Zhang, C.; Dong, H.; Zhao, J. A synthetic model for the oxygen-evolving complex in Sr ${ }^{2+}$-containing photosystem II. Chem. Commun. 2014, 50, 9263-9265. [CrossRef]

114. Cardona, T.; Rutherford, A.W. Evolution of photochemical reaction centres: More twists? Trends Plant Sci. 2019, 24, 1008. [CrossRef]

115. Dasgupta, J.; Ananyev, G.M.; Dismukes, G.C. Photoassembly of the water-oxidizing complex in photosystem II. Coord. Chem. Rev. 2008, 252, 347-360. [CrossRef]

116. Zhang, M.; Bommer, M.; Chatterjee, R.; Hussein, R.; Yano, J.; Dau, H.; Kern, J.; Dobbek, H.; Zouni, A. Structural insights into the light-driven auto-assembly process of the water-oxidizing $\mathrm{Mn}_{4} \mathrm{CaO}_{5}$-cluster in photosystem II. eLife 2017, 6, e26933. [CrossRef]

117. Vinyard, D.J.; Badshah, S.L.; Riggio, M.R.; Kaur, D.; Fanguy, A.R.; Gunner, M.R. Photosystem II oxygen-evolving complex photoassembly displays an inverse $\mathrm{H} / \mathrm{D}$ solvent isotope effect under chloride-limiting conditions. Proc. Natl. Acad. Sci. USA 2019, 116, 18917-18922. [CrossRef]

118. Zhang, C.; Chen, C.; Dong, H.; Shen, J.R.; Dau, H.; Zhao, J. A synthetic $\mathrm{Mn}_{4}$ Ca-cluster mimicking the oxygen-evolving center of photosynthesis. Science 2015, 348, 690-693. [CrossRef]

119. Boussac, A.; Rutherford, A.W. Comparative study of the $g=4.1 \mathrm{EPR}$ signals in the $\mathrm{S}_{2}$ state of photosystem II. Biochim. Biophys. Acta 2000, 1457, 145-156. [CrossRef]

120. Pantazis, D.A.; Ames, W.; Cox, N.; Lubitz, W.; Neese, F. Two interconvertible structures that explain the spectroscopic properties of the oxygen-evolving complex of photosystem II in the $\mathrm{S}_{2}$ state. Angew. Chem. Int. Ed. 2012, 51, 9935-9940. [CrossRef]

121. Dismukes, G.C.; Siderer, Y. Intermediates of a polynuclear manganese center involved in photosynthetic oxidation of water. Proc. Natl. Acad. Sci. USA 1981, 78, 274-278. [CrossRef]

122. Boussac, A.; Ugur, I.; Marion, A.; Sugiura, M.; Kaila, V.R.I.; Rutherford, A.W. The low spin-high spin equilibrium in the $\mathrm{S}_{2}$-state of the water oxidizing enzyme. Biochim. Biophys. Acta 2018, 1859, 342-356. [CrossRef]

123. Chatterjee, R.; Lassalle, L.; Gul, S.; Fuller, F.D.; Young, I.D.; Ibrahim, M.; Lichtenberg, C.D.; Cheah, M.H.; Zouni, A.; Messinger, J.; et al. Structural isomers of the $S_{2}$ state in photosystem II: Do they exist at room temperature and are they important for function? Physiol. Plant. 2019, 166, 60-72. [CrossRef]

124. Bovi, D.; Narzi, D.; Guidoni, L. The $S_{2}$ state of the oxygen-evolving complex of photosystem II explored by QM/MM dynamics: Spin surfaces and metastable states suggest a reaction path towards the $\mathrm{S}_{3}$ state. Angew. Chem. Int. Ed. 2013, 52, 11744-11749. [CrossRef]

125. Corry, T.A.; O'Malley, P.J. Proton isomers rationalize the high- and low-spin forms of the $S_{2}$ state intermediate in the water-oxidizing reaction of photosystem II. J. Phys. Chem. Lett. 2019, 10, 5226-5230. [CrossRef]

126. Shoji, M.; Isobe, H.; Shen, J.R.; Yamaguchi, K. Geometric and electronic structures of the synthetic $\mathrm{Mn}_{4} \mathrm{CaO}_{4}$ model compound mimicking the photosynthetic oxygen-evolving complex. Phys. Chem. Chem. Phys. 2016, 18, 11330-11340. [CrossRef]

127. Paul, S.; Cox, N.; Pantazis, D.A. What can we learn from a biomimetic model of nature's oxygen evolving complex? Inorg. Chem. 2017, 56, 3875-3888. [CrossRef]

128. Pushkar, Y.; Ravari, A.K.; Jensen, S.C.; Palenik, M. Early binding of substrate oxygen is responsible for a spectroscopically distinct $S_{2}$ state in photosystem II. J. Phys. Chem. Lett. 2019, 10, 5284-5291. [CrossRef]

129. Mino, H.; Nagashima, H. Orientation of ligand field for dangling manganese in photosynthetic oxygen-evolving complex of photosystem II. J. Phys. Chem. B 2020, 124, 128-133. [CrossRef]

130. Chen, C.; Li, Y.; Zhao, G.; Yao, R.; Zhang, C. Natural and artificial $\mathrm{Mn}_{4} \mathrm{Ca}$ cluster for the water splitting reaction. ChemSusChem 2017, 10, 4403-4408. [CrossRef]

131. Kuang, T. A breakthrough of artificial photosynthesis. Nat. Sci. Rev. 2016, 3, 2-3. [CrossRef]

132. Yu, Y.; Hu, C.; Liu, X.; Wang, J. Synthetic model of the oxygen-evolving center: Photosystem II under the spotlight. ChemBioChem 2015, 16, 1981-1983. [CrossRef] 
133. Barber, $\mathrm{J} . \mathrm{Mn}_{4}$ Ca cluster of photosynthetic oxygen-evolving center: Structure, function and evolution. Biochemistry 2016, 55, 5901-5906. [CrossRef]

134. Sun, L. A closer mimic of the oxygen evolution complex of photosystem II. Science 2015, 348, $635-636$. [CrossRef]

(c)

(C) 2020 by the authors. Licensee MDPI, Basel, Switzerland. This article is an open access article distributed under the terms and conditions of the Creative Commons Attribution (CC BY) license (http://creativecommons.org/licenses/by/4.0/). 